\title{
Developments in support materials for immobilization of oxidoreductases: A
} comprehensive review

\author{
Zdarta, Jakub; Meyer, Anne S.; Jesionowski, Teofil; Pinelo, Manuel
}

Published in:

Advances in Colloid and Interface Science

Link to article, DOI:

10.1016/j.cis.2018.07.004

Publication date:

2018

Document Version

Peer reviewed version

Link back to DTU Orbit

Citation (APA):

Zdarta, J., Meyer, A. S., Jesionowski, T., \& Pinelo, M. (2018). Developments in support materials for immobilization of oxidoreductases: A comprehensive review. Advances in Colloid and Interface Science, 258, 120. https://doi.org/10.1016/j.cis.2018.07.004

\section{General rights}

Copyright and moral rights for the publications made accessible in the public portal are retained by the authors and/or other copyright owners and it is a condition of accessing publications that users recognise and abide by the legal requirements associated with these rights.

- Users may download and print one copy of any publication from the public portal for the purpose of private study or research.

- You may not further distribute the material or use it for any profit-making activity or commercial gain

- You may freely distribute the URL identifying the publication in the public portal 


\section{Accepted Manuscript}

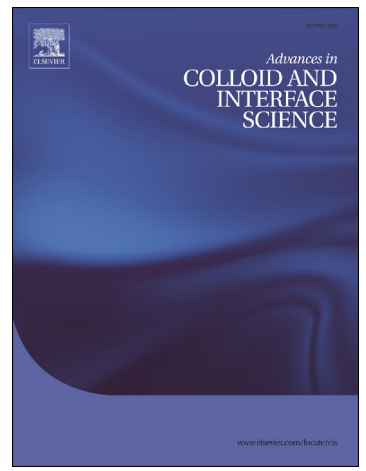

Jakub Zdarta, Anne S. Meyer, Teofil Jesionowski, Manuel Pinelo

PII:

S0001-8686(18)30084-8

DOI:

doi:10.1016/j.cis.2018.07.004

Reference:

CIS 1901

To appear in:

Advances in Colloid and Interface Science

Please cite this article as: Jakub Zdarta, Anne S. Meyer, Teofil Jesionowski, Manuel Pinelo, Developments in support materials for immobilization of oxidoreductases: A comprehensive review. Cis (2018), doi:10.1016/j.cis.2018.07.004

This is a PDF file of an unedited manuscript that has been accepted for publication. As a service to our customers we are providing this early version of the manuscript. The manuscript will undergo copyediting, typesetting, and review of the resulting proof before it is published in its final form. Please note that during the production process errors may be discovered which could affect the content, and all legal disclaimers that apply to the journal pertain. 


\section{Developments in support materials for immobilization of oxidoreductases:}

\section{A comprehensive review}

Jakub Zdarta ${ }^{1,2, *}$, Anne S. Meyer ${ }^{2}$, Teofil Jesionowski ${ }^{1}$, Manuel Pinelo ${ }^{2}$

${ }^{1}$ Institute of Chemical Technology and Engineering,

Faculty of Chemical Technology, Poznan University of Technology, Berdychowo 4, PL-60965 Poznan, Poland

${ }^{2}$ Department of Chemical and Biochemical Engineering,

Center for BioProcess Engineering, Technical University of Denmark,

Soltofts Plads 229, DK-2800 Kgs. Lyngby, Denmark

Corresponding author:

jakub.zdarta@put.poznan.pl 


\begin{abstract}
Bioremediation, a biologically mediated transformation or degradation of persistent chemicals into nonhazardous or less-hazardous substances, has been recognized as a key strategy to control levels of pollutants in water and soils. The use of enzymes, notably oxidoreductases such as laccases, tyrosinase, various oxygenases, aromatic dioxygenases, and different peroxidases (all of EC class 1) is receiving significant research attention in this regard. It should be stated that immobilization is emphasized as a powerful tool for enhancement of enzyme activity and stability as well as for protection of the enzyme proteins against negative effects of harsh reaction conditions. As proper selection of support materials for immobilization and their performance is overlooked when it comes to comparing performance of immobilized enzyme in academic studies, this review summarizes the current state of knowledge regarding the materials used for enzyme immobilization of these oxidoreductase enzymes for environmental applications. In the presented study, thorough physicochemical characteristics of the support materials was presented. Moreover, various types of reactions and notably operational modes of enzymatic processes for biodegradation of harmful pollutants are summarized, and future trends in use of immobilized oxidoreductases for environmental applications are discussed. Our goal is to provide an improved foundation on which new technological advancements can be made to achieve efficient enzyme-assisted bioremediation.
\end{abstract}

Keywords: support materials, materials properties, enzyme immobilization, oxidoreductases, hazardous pollutants, environmental protection 


\section{Table of Contents}

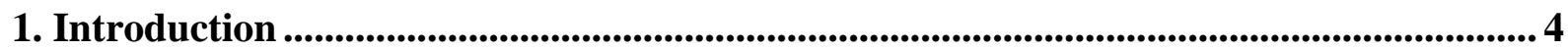

2. Enzymes for environmental applications............................................................................... 6

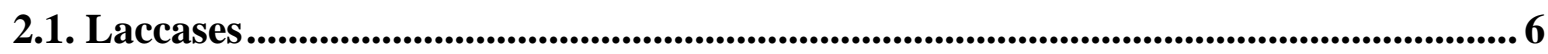

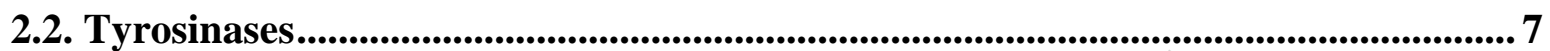

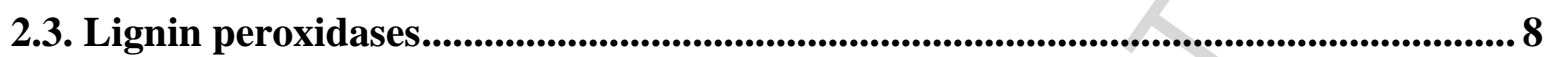

2.4. Manganese peroxidases.................................................................................................. 9

2.5. Horseradish peroxidases...............................................................................................9

3. Immobilization of enzymes .................................................................................................... 10

4. Materials for immobilization of enzymes used for environmental protection .............. 12

4.1. Materials of organic origin ............................................................................................ 12

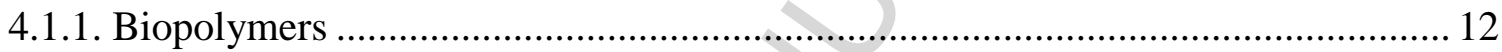

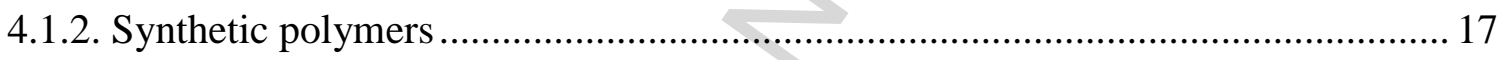

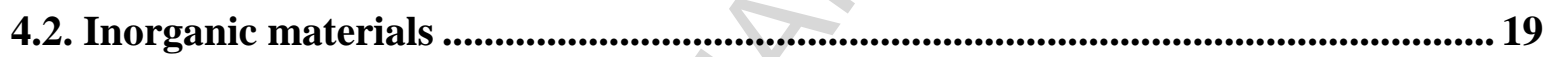

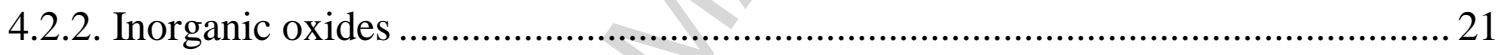

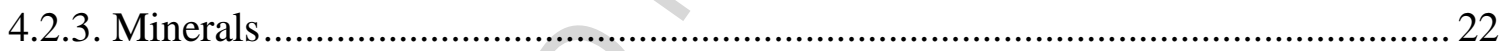

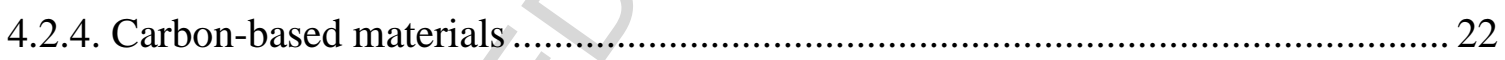

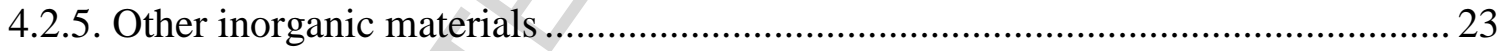

4.3. Hybrid materials ................................................................................................................. 25

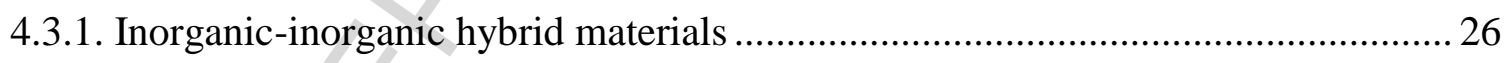

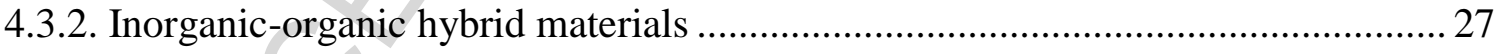

4.3.3. Organic-organic hybrid materials.................................................................... 28

5. Effect of support materials and immobilization technique on substrates accessibility 31

6. Summary and comparison of support material of various origin ..................................... 32

7. General summary and remarks .................................................................................................36 


\section{Introduction}

Over recent years the production and wide application of synthetic chemical compounds has become essential in many branches of industry. There are, however, some serious drawbacks related to the use of these compounds because they are poorly biodegradable [1]. Interest therefore continues to grow in remediation of endocrine disrupting chemicals (EDCs), hormones, pesticides, synthetic dyes and pharmaceuticals because these substances may alter the functions of hormonal and nervous systems, cause diseases of the male and female reproductive system, disorders and alterations of neurological and metabolism and cause adverse effects in intact organisms [2-4]. These synthetic chemicals exhibit genotoxic activity, can cause diabetes, obesity, cardiovascular diseases, reproductive disorder or even cancer $[5,6]$. Another cause for serious environmental concern is pollution of communal wastewater and effluents released by the textile or paper industries, agriculture or houses. Nowadays, there are a plenty of both physical and chemical methods for removal of persistent compounds. One of the most effective and eco-friendly of these methods is application of enzymes for biodegradation of hazardous pollutants.

Enzymes have for years been known as extremely efficient and highly effective biocatalysts that additionally are characterized by high chemo-, regio- and stereoselectivity. Furthermore, enzymes through decreasing the amount of toxic solvents and reducing the number of synthesis steps and activation energy, make the catalytic process more cost-effective and environmentally friendly [7]. In the current review, attention is given to laccases, tyrosinases, manganese and horseradish, lignin and phenol peroxidases, however also other oxidoreductases such as monooxygenases, oxygenases and even oxidases might be employed as highly efficient green biocatalysts for remediation of environmental pollutions [8], but literature references about efficient immobilization of monooxygenases and oxygenases for environmental protection are strongly limited. Above-mentioned types of enzymes are able to catalyze redox-transformations and degradation of a large number of organic compounds, in particular phenolic and non-phenolic aromatic compounds such as phenol and its derivatives, EDCs, synthetic and natural dyes, pesticides and pharmaceuticals $[9,10]$. The catalytic action of these enzymes might range from simple transformation of contaminants to less toxic derivatives to manipulation of contaminated environments or even to bioaccumulation of pollutants [11]. 
Enzyme immobilization can be accomplished in various ways, but usually involves attachment of the enzyme molecules to a solid carrier, which is usually insoluble in the reaction environment [12]. The result is immobilized biocatalyst where the form of the enzyme has been changed from homogenous (free enzyme) to heterogeneous (immobilized enzyme). Enzyme immobilization allows maximal reuse or recycling of the enzyme in continuous processes where the substrate is fed continuously into the reaction to increase the biocatalytic productivity (amount of substrate molecules converted per amount of enzyme). Immobilized enzymes are usually characterized by enhanced stability against harsh conditions of $\mathrm{pH}$, temperature and pressure [13]. Moreover, storage stability and reusability of the immobilized biocatalyst increases significantly compared with free enzyme [14]. So it could be summarized that immobilization represent simple and effective routes for improvement of enzyme properties as compared to application of the native biocatalysts [15]. The five main immobilization techniques are covalent binding, adsorption, encapsulation, entrapment and cross-linking. However, it should be emphasized that there is no universal method for any particular enzyme [16]. Selection and optimization of the most suitable support material and technique of immobilization is dependent on the type of the enzyme and biocatalytic process. It should also be mentioned that proper selection of support for enzymes such as laccases or tyrosinases for environmental applications not only ensured highly efficient biodegradation of toxic compounds but also protected enzyme molecules from denaturation and allowed their reusability [17]. Many different materials can potentially be used as support materials for enzyme immobilization. Nevertheless, the material has to fulfil some requirements in order to be used as a carrier. First, physicochemical features like the presence of chemical moieties, large surface area or good sorption properties are crucial for establishing of strong and stable interactions between the enzyme and a support material [18]. It is crucial that for environmental use, support materials should also be biocompatible, non-toxic, and environmentally friendly/acceptable and cannot negatively affect solution after biodegradation. Also, hydrophilicity of the carrier, its structure and mechanical or operational stability stronglfy affect the properties of the produced biocatalytic system and ultimately determine successful immobilization [19]. It should be stressed that for attachment of a biocatalyst for environmental applications, materials of organic, inorganic as well as hybrid or composite origin have been frequently studied [20]. Their selection is dictated by type of enzyme, type of biocatalytic conversion, character of the process and required form and shape of biocatalytic beads, all of which influence the efficiency of the whole bioremediation process [21]. 
The present review briefly describes various immobilization protocols used for binding of oxidoreductases. The main purpose of the literature study was to summarize and compare the current state of knowledge about support materials for enzyme immobilization with particular reference to immobilization of laccases, tyrosinases and phenyloxidases and use of the resulting biocatalytic systems in the removal of hazardous pollutants. The properties of inorganic, organic and hybrid support materials required for effective enzyme binding are specified and presented. Various types and configurations of degradation processes, and types of reactors are highlighted. Furthermore, the effect of operational parameters such as time, $\mathrm{pH}$ and temperature on the removal efficiencies of undesirable compounds are compared, as well as storage stability and reusability of the immobilized biocatalysts. We also discuss present and future perspectives for application of immobilized oxidoreductases for environmental protection with emphasis on pollutants removal.

\section{Enzymes for environmental applications}

As previously mentioned, enzymes belonging to the oxidoreductases (EC 1), such as laccases, tyrosinases, manganese, lignin and horseradish peroxidases, and phenoloxidases, are the most frequently employed for environmental applications [22]. These enzymes are being investigated due to their applicability as "green catalysts" in the bioremediation of various dangerous chemicals such as phenols and derivatives, bisphenols, organic dyes or pharmaceuticals [23]. They have been found to be efficient biocatalysts for remediation of toxic compounds, but the structures, cofactors and mechanisms of action differ for each type of catalyst. Selected examples of the enzymes most frequently used for environmental protection are discussed in detail below.

\subsection{Laccases}

Laccases of various origin are the most commonly used environmental protection. Laccases, which are extracellular enzymes also known as $p$-diphenol: dioxygen oxidoreductases(EC 1.10.3.2), are oxidoreductases omnipresent in plants and bacteria, however, laccases from fungi like Trametes versicolor, Trametes vilosa or Cerrena unicolor are of the greatest interest due to their high catalytic activity, availability and low price [24]. Laccases, due to their low substrate specificity, are enzymes that can catalyze wide range of reactions, mainly one-electron oxidation of monophenols, diphenols and polyphenols as well as diamines, aromatic amines and related substances such as $\mathrm{N}$-heterocycles, phenothiazines and many others. These oxidation processes generate reactive phenoxy radicals with a simultaneous 
reduction of oxygen to water, without the need for hydrogen peroxide [25]. These laccases constitute a wide group of multi-copper oxidase enzymes that contain four copper ions in their structure that exhibit different properties. At a type-1 copper atom (T1) is responsible for the blue color of the laccase and together with the type-2 atom (T2) and two atoms of type 3 (T3) take part in oxidation-reductions reactions catalyzed by laccases [26]. In detailed, the bioconversion acts are initiated at the type-1 copper atom where electrons from substrate molecules are extracted and transferred via His-Cys-His triade to the T2/T3 group. Further, accumulated electrons enable the oxidation reaction and simultaneously allow the reduction of molecular oxygen to water [27]. It also should be added that laccases are employed in various applications such as in the food, textile, fuel and medical industries [28]. Due to their wide substrate specificity and ubiquitous properties, they are able to act on a wide range of phenolic compounds and are increasingly used for bioremediation of environmental pollutants from soils and water [29,30]. The example of the catalytic pathways of conversion of bisphenol A and tetracycline by laccase are presented in Fig. 1. Most laccases are extracellular proteins with isoelectric points ranging from 3 to 7 for fungal laccases and around 9 for plant laccases. Moreover, differences in optimal $\mathrm{pH}$ for both sources of laccases have been found: fungal laccases exhibit maximal catalytic properties at $\mathrm{pH}$ between 3.5 and 5 as laccases from plants have $\mathrm{pH}$ optima around $\mathrm{pH}$ 7. Differences in the temperature optima between various laccases have also been found [31].

\section{Figure 1}

\subsection{Tyrosinases}

Tyrosinases, $o$-diphenol: oxygen oxidoreductases (EC 1.14.18.1), also contain copper atoms in their active site. These copper atoms are known as $\mathrm{CuA}$ and $\mathrm{CuB}$ and are coordinated by histidine residues [34].Tyrosinases are frequently abundant in nature and are found in plants, fungi, bacteria, insects and in mammalian issues [35]. They play a key role in the synthesis of melanin - the dye that is responsible for the color of human skin. Tyrosinases differ essentially from laccases in the mechanism of oxidation of phenol and its derivatives. Although tyrosinases also use oxygen as a cofactor, they generate quinones instead of free radicals and water molecules as a by-product [36]. The mechanism of catalytic action of tyrosinases has been defined as a two-step consecutive reaction of monophenol hydroxylation to corresponding ortho-diphenols and their further oxidation to ortho-quinones using $\mathrm{O}_{2}$ molecules in both steps. Later release of water molecules terminates catalytic oxidation and 
leads to a polymerization reaction of $o$-quinones to macromolecular compounds [37].Due to the fact that tyrosinases can occur in various molecular forms, different intermediates may be formed during catalysis of phenolic compounds [9].It should be clearly stated that due to their wide specificity, tyrosinases similarly to laccases are able to catalyze transformation of various compounds such as phenol, monophenols and its multisubstituted derivatives, including chloro- and nitrophenols and bisphenols [38].The effect of temperature and $\mathrm{pH}$ on the stability and activity of various tyrosinases has been thoroughly analyzed. A previous study reported $\mathrm{pH}$ ranging from 5.5 to 8 as the most suitable for the highest activity of free tyrosinases [39].The effect of temperature on the activity of tyrosinases has also been studied. Published data showed that free tyrosinases exhibit the highest activity at temperatures ranging from 30 to $40^{\circ} \mathrm{C}$ and that activity significantly decreases above $60^{\circ} \mathrm{C}$.It should be added that most of tyrosinases under optimal conditions exhibit relatively good stability and retain high activity (80-100\%) even for $8 \mathrm{~h}[40]$.

\section{Figure 2}

\subsection{Lignin peroxidases}

Besides laccases and tyrosinases, lignin peroxidases are also used for remediation of hazardous phenolic compounds from water and soil. Lignin peroxidase, 1,2-bis(3,4dimethoxyphenyl)propane-1,3-diol:hydrogen peroxide oxidoreductase (EC 1.11.1.14), also known as LiP, contains 1 mole of iron protoporphyrin (heme) as its cofactor for 1 mole of protein [41]. Lignin peroxidases catalyze the oxidative depolymerization of lignin in the presence of $\mathrm{H}_{2} \mathrm{O}_{2}$. Exemplary reaction, which characterizes catalytic action of LiP (oxidation of 1,2-bis(3,4-dimethoxyphenyl)propane-1,3-diol) could be presented as [42]:

1,2-bis(3,4-dimethoxyphenyl)propane-1,3-diol $+\mathrm{H}_{2} \mathrm{O}_{2} \leftrightarrow$

3,4-dimethoxybenzaldehyde+1-(3,4-dimethoxyphenyl)ethane-1,2-diol $+\mathrm{H}_{2} \mathrm{O}$.

It should be added that LiP is characterized by low substrate specificity with high, nonspecific oxidation-reduction potential and is known for its ability to oxidize aromatic phenolic and non-phenolic compounds as well as a wide range of organic chemical compounds, such as xenobiotics with a redox potential of up to $1.4 \mathrm{~V}$ [43]. LiP was extracted for the first time from Phanerochaete chrysosporium but these enzymes are also known to be found in many microorganisms and white-rot fungi [44]. It should be mentioned further that lignin 
peroxidase is known from its low optimum $\mathrm{pH}$ value, as these enzymes reach their maximum catalytic activity at a $\mathrm{pH}$ near 3 . The temperature optimum for $\mathrm{LiP}$ is similar to other peroxidases and is within a range of 40 to $50^{\circ} \mathrm{C}$ [45].

\subsection{Manganese peroxidases}

Another enzyme with high biotechnology potential that belongs to the oxidoreductase group is manganese peroxidase (EC 1.11.1.13), also known as $\mathrm{Mn}$ (II):hydrogen-peroxide oxidoreductase orMnP. These glycosylated heme-containing enzymes can oxidize a wide variety of phenolic compounds, such as dyes and various monomeric and dimeric phenols as well as oxidize $\mathrm{Mn}$ (II) ions to $\mathrm{Mn}$ (III) using hydrogen peroxide [46]. The catalytic cycle of $\mathrm{MnP}$ is initiated by binding of $\mathrm{H}_{2} \mathrm{O}_{2}$ and formation of an iron-peroxide complex and subsequent transfer of 2 electrons from the heme resulting in formation of MnP Compound I. Later, one water molecule is formed by subsequent cleaving of the dioxygen bond and reduction proceeds through $\mathrm{MnP}$ Compound II. Afterwards, monochelated $\mathrm{Mn}^{2+}$ ion acts as electron donor for this porphyrin intermediate and is oxidized to $\mathrm{Mn}^{3+}$. Another $\mathrm{Mn}^{3+}$ is formed by reduction of Compounds II leading to regeneration of native enzyme and releasing of the second water molecule [47].Manganese peroxidase is a protein found in multiple forms with a typical molecular weight ranging from 40 to $50 \mathrm{kDa}$ [47]. MnPs exhibit their maximal activity at $\mathrm{Mn}(\mathrm{II})$ concentrations above $100 \mu \mathrm{M}$ and calcium cations enhance their catalytic properties [48]. Manganese peroxidase was discovered for the first time in P. chrysosporium but in later years the enzyme has also been found in bacteria and other white-rot fungi [49]. The optimum temperature for the highest catalytic activity of manganese peroxidases depends on its source, but in most cases lies the range of 30 to $40^{\circ} \mathrm{C}$. These enzymes exhibit their highest catalytic properties at slightly acidic pH levels of around 4 [50].

\subsection{Horseradish peroxidases}

Enzymes extracted from the roots of horseradish have also been assessed in environmental applications. A number of distinctive peroxidase isoenzymes have been found in nature, however, the most abundant is horseradish peroxidase $\mathrm{C}$ [51]. Horseradish peroxidase (EC 1.11.1.7) or HRP is also a heme-containing enzyme that includes in its structure iron(III) protoporphyrin and two atoms of calcium. The presence of calcium atoms is important, because loss of calcium results in significant decrease of enzyme activity and thermal stability [52]. Horseradish peroxidase catalyzes an oxidation reaction of phenolic acids, aromatic phenols such as pyrogallol and their derivatives (i.e. various bisphenols), non-aromatic 
amines such as 4-aminoantipyrine, indoles, etc. in the presence of hydrogen peroxide, producing two molecules of water. The second products of the catalytic reaction are radicals that can result in formation of polymeric compounds as the final products of oxidation [53,54]. The main practical applications of HRPs includes treatment of the wastewaters contain phenolic compounds, environmental remediation, elimination of toxic compounds such as dyes from drinking water and industrial [55-57]. HRP, particularly its isoenzyme C, exhibits its greatest catalytic activity at temperatures of $25-40^{\circ} \mathrm{C}$ and at neutral $\mathrm{pH}$, close to 7 [58].

In recent years, lignolytic enzymes, such as laccase, tyrosinase, manganese, lignin and horseradish peroxidases have been used in numerous industrial processes, such biomass conversion and chemical synthesis. However their great oxidizing potential caused that they have found an application in environmental protection to degrade xenobiotics, as dyes, pharmaceuticals and hazardous pollutants that are usually resistant to microbial biodegradation [59]. In our opinion, further study leading to the development of the techniques that improve practical features of the lignolytic enzymes is highly required as might facilitate use of these important biomolecules for various biotechnology applications and environmental protection.

\section{Immobilization of enzymes}

Many advanced research studies have been carried out in connection with the low stability and reusability of enzymes. Immobilization, a process through which the enzyme is bound to a solid support, changes the form of the catalyst from homogenous (free enzyme) to heterogenous (immobilized enzyme) [60]. Creation of interactions between the enzyme and a matrix (immobilization) stabilizes the peptide structure of the biocatalyst and results in improvement of enzyme stability towards strong $\mathrm{pH}$, high temperature or the presence of organic solvents [61].The possibility of separation of the biocatalytic system from the reaction mixture is strongly enhanced and thus contamination of products by the enzyme particles is minimalized. Additionally, after the immobilization, the biocatalysts can easily be removed by simple mechanical separation or centrifugation without using sophisticated analytical techniques. However, the greatest advantage of immobilization is the production of an enzymatic system that could be reused in many catalytic cycles without significant loss of its unique properties [62,63].

According to the previously published reviews, methods of immobilization have been classified in many different ways [64-66]. The techniques differ between each other by the 
types of the created interactions and by type and form of the solid support. In each case, for selection of the immobilization technique, a compromise has been made between retention of high catalytic activity and operational benefits. For the purpose of the current discussion, five different immobilization techniques are distinguished, namely: (i) non-covalent (adsorption) immobilization; (ii) covalent immobilization on a carrier; (iii) encapsulation; (iv) entrapment and (v) cross-linking of the enzyme particles by creation of the cross-linked enzyme aggregates (CLEA) and cross-linked enzyme crystals (CLEC), as summarized in Table 1.

\section{Table 1}

Non-covalent immobilization, also known as adsorption immobilization, is based on the creation of non-specific interactions mainly via hydrogen bonds and ionic and hydrophobic interactions. In effect, conformational changes in the enzyme particle are limited and retention of high catalytic activities by the immobilized enzymes is usually observed $[67,68]$. Immobilization by covalent binding is based on the reaction of functional groups of the support material with functional groups of the enzyme (mainly $-\mathrm{NH}_{2},-\mathrm{SH}$ and $-\mathrm{OH}$ ). Creation of strong chemical bonds between the biocatalyst and matrix significantly reduces leakage of the enzyme and enhances the reusability of the enzyme [69,70]. When the biomolecule is immobilized by encapsulation or entrapment it is physically placed in the pores of the support material but its structure remains unaltered. Single enzymes as well as complex biocatalytic systems built from different types of enzymes may by immobilized by the use of these methods. The disadvantage of these techniques is that due to the location of the enzyme within the porous system of the matrix, transfer of the reaction mixture ingredients is more difficult [71]. Enzymes in the form of single crystals (CLEC) or as aggregates (CLEA) are cross-linked within bifunctional compounds such as glutaraldehyde (GA) or carbodiimides. Establishing covalent bonds through the use of cross-linking agents allows formation of a stable structure without the use of a solid support [72,73].

Different techniques could be applied for immobilization of the same enzyme, however, changes in the enzyme structure and its properties are usually not equal with improvements of the biocatalysts properties. Thus, mild process conditions are highly required to retain good catalytic properties of the immobilized enzymes. Moreover, the more simple is the immobilization method, such as adsorption immobilization, the more cost effective is the process. As every enzyme differ from each other, it could be concluded that 
proper selection of the immobilization protocol is a key step to obtain biocatalytic systems which might be applied for practical applications.

\section{Materials for immobilization of enzymes used for environmental protection}

As was mentioned earlier, the main purpose of the current review is to present and characterize various enzyme support materials that can be applied in processes related to environmental protection. Free oxidoreductases have been applied for removal of micropollutants from environments, however, large-scale use of these enzymes in biodegradation requires their immobilization to increase stability and prolong activity [74]. These biocatalysts can be immobilized through the use of various materials of different origin, from inorganic through organic to hybrids and composite supports. The most important properties of selected examples of these support materials are presented in Fig. 3.The great variety of the possible carriers with regard to shapes, sizes and forms means that enzymes can be immobilized via various methodologies. In this section the effect of different features of support material on enzyme activity and biodegradation efficiency is presented and discussed.

\section{Figure 3}

\subsection{Materials of organic origin}

Many different materials of organic origin, both natural and synthetic, have been employed for immobilization of enzymes for environmental protection using different immobilization techniques (Table 2).

\section{Table 2}

\subsubsection{Biopolymers}

\subsubsection{Chitosan}

As was previously stated, chitosan is one of the most frequently used support materials for immobilization due to its easy availability, low cost, biocompatibility and hydrophilicity. The presence of many hydroxyl and amine groups in the structure of this biopolymer facilitates effective binding of laccases and other peroxidases without involving any modifying or crosslinking agents [111]. The ability of chitosan to create various forms, such as fibers, beads, microspheres or membranes, enhances its application as a support material for enzymes like laccase or lignin peroxidase and makes immobilized biomolecules more stable. For instance, 
Zhang et al. have covalently attached laccase from Coriolus versicolor via glutaraldehyde to the surface of chitosan. The obtained biocatalytic system was used for biodegradation of mono- and dichlorophenols and brought about the degradation of over $90 \%$ of 2,4dichlorophenol in water solution. Moreover, immobilized enzyme was characterized by higher stability in comparison to free enzyme and exhibited good reusability [75]. In another study, chitosan, chitosan microspheres with high specific surface area and chitosan beads were used for immobilization of laccase, manganese peroxidase and lignin peroxidase by entrapment, covalent binding and adsorption, respectively. The produced biocatalysts, due to their wide specificity, were used for degradation of synthetic and natural azo-dyes in model and real water solutions. Enzymatic systems are characterized by various thermal and chemical stabilities, but under optimal conditions (temperature range $30-50{ }^{\circ} \mathrm{C}$, $\mathrm{pH}$ range 58) they usually enable degradation of over $70 \%$ of the pollutants. Lack of electron mediator and low transfer of the electrons as well as complicated structure of the dyes are the main factors, which limit biodegradation efficiency [78]. However, the presence of the mediator agent is not necessary for total degradation of the contaminating dye. As Jaiswal et al. have shown, after $8 \mathrm{~h}$ at $37^{\circ} \mathrm{C}$ laccase from papaya entrapped in chitosan beads was able to remove Indigo carmine completely from water solution due among other factors to low diffusional limitation [79].

\subsubsection{Alginates}

Other extensively used support materials for environmental applications of enzymes are various alginate salts derived from brown algae, Phaeophyceae, under alkaline conditions. After gelation under mild conditions after addition of mono- or divalent cations like $\mathrm{Na}^{+}$, $\mathrm{Ca}^{2+}, \mathrm{Cu}^{2+}, \mathrm{Zn}^{2+}$ and $\mathrm{Mn}^{2+}$ [112], alginates are characterized by viscosity and stiffness, which can easily be controlled by manipulation of the $\mathrm{pH}$ and molecular weight of the alginate solution. For enzyme immobilization, alginates are used in the form of beads, hydrogels and capsules. And as a consequence of the features and diversity of form of alginates, immobilization of laccases, tyrosinases and other peroxidases by alginates mainly occurs through entrapment and encapsulation. Usually, after biomolecules have been immobilized in alginates, there is a lack of covalent bonds between the enzyme and a support, and thus functional groups of the matrix and the enzyme interact based on relatively weak, ionic or adsorption forces [113]. Because interference in the structure of the enzyme is strongly limited, immobilized enzymes usually retain most of their catalytic properties. On the other hand, creation of relatively weak interactions might lead to leakage of the enzyme from the 
matrix and result in a decrease in biocatalytic activity of the produced system. Additionally, lower catalytic properties may be related to diffusional limitations in transport of the substrates and the products through the alginates layer. Sodium and calcium ions are the most commonly used ions for gelation of alginates. For instance, calcium alginate was used for immobilization of manganese peroxidase from G. lucidum and tyrosinase from Agaricus bisporus [80,81], and tyrosinase from Streptomyces espinosus and laccase from Bacillus subtilis were entrapped in sodium alginate [82,83]. Irrespective of metal cation used for gelation, immobilized tyrosinases were used for removal of phenol from water solutions. Immobilized enzyme exhibited high catalytic activity and under optimal conditions was able to totally degrade phenol from solution after $1 \mathrm{~h}$ of the process [81]. Silica ions have also been used to increase the mechanical stability of the alginate. Silica alginates were further used for encapsulation and entrapment of tyrosinase and the obtained biocatalytic system then applied for biodegradation of bisphenol A (BPA). This biocatalytic system not only allowed highly efficient removal of BPA in a relatively short time, but most of all was characterized by much higher $\mathrm{pH}$ and temperature resistance in comparison to free enzyme. However, fast drop of the catalytic properties over consecutive catalytic cycles related to the enzyme leakage should be presented as the weak point of this study [85]. Special attention should also be paid to copper alginates as supports for environmentally enzymes. Due to the fact that laccase contains three different copper ions in its structure, utilization of supports containing copper ions increases the bioactivity of the immobilized biomolecules. Laccases or polyphenol oxidases were entrapped and encapsulated in materials prepared in this way and used for degradation of natural and synthetic dyes and phenol derivatives with removal efficiencies that reached over $80 \%$. However, the significant effect of copper ions on the immobilized enzyme should be emphasized. Phetsom et al. encapsulated laccase from Lentinus polychrous in $\mathrm{Cu}$-alginate beads. The immobilized biomolecule exhibited more than two times the catalytic activity of free enzyme after 7 days of storage at $\mathrm{pH} 5.5$ due to the presence of $\mathrm{Cu}^{2+}$ ions [91]. Alginates are also used in the form of beads for immobilization mainly by entrapment of laccases, tyrosinases and various peroxidases. Due to the mechanical stability of the capsules with biomolecules that form beads, these products are commonly employed in bioreactors of different configurations used for degradation of synthetic textile dyes as well as phenol and its derivatives in water solutions. As reported by Daassi et al., laccase from Coriolopsis gallica immobilized in alginate beads exhibited over $80 \%$ of its catalytic activity over a wide $\mathrm{pH}$ range from 5 to 9 , but the free enzyme was most active only at $\mathrm{pH} 7$. Furthermore, immobilized biocatalyst was characterized by high thermal stability. After 
incubation for $3 \mathrm{~h}$ at $55{ }^{\circ} \mathrm{C}$, immobilized laccase still exhibited over $80 \%$ of initial activity, meanwhile free laccase under the same conditions completely lost its properties after $2 \mathrm{~h}$ of heating [88].

\subsubsection{Cellulose}

Another organic material used as support for environmental enzymes is cellulose and its modified forms. Cellulose is known from its great sorption capacity and the presence of many hydroxyl groups in its structure. This facts allows effective attachment of enzyme molecules and enhances opportunities for modification of cellulose surfaces by glutaraldehyde, diethylaminoethanol or introduction of epoxy groups [114]. Cellulose is also relatively easy to obtain, is nontoxic and biocompatible. The abovementioned features taken together mean that cellulose and its derivatives are suitable support materials for adsorption or covalent immobilization of oxidoreductase enzymes. Application of cellulose-based materials is therefore growing quickly as a response to the importance of sustainable and cost-effective immobilization. As a result, many new cellulosic materials with desired properties and stability are under development for attachment of biomolecules. Sathishkumar et al. used cellulose nanofibers modified by glutaraldehyde for covalent immobilization of laccase. Thermal and $\mathrm{pH}$ stability as well as storage stability of the immobilized enzyme was considerably improved compared to the free enzyme. Laccase-cellulose nanofibers also exhibited great reusability and retained over $80 \%$ of the initial properties after five catalytic cycles. The biocatalyst thus obtained was applied for decolorization of simulated dye effluent (SDE) consisting of Remazol Black 5, Remazol Brilliant Blue R, Remazol Brilliant Violet 5R, Reactive Orange 16 and Reactive Red 120. The authors demonstrated that in the presence of the mediator, 1-hydroxybenzotriazole, decolorization of SDE reached around $40 \%$. Although the stability of the immobilized enzyme was improved, changes in the structure of biomolecules due to covalent binding, caused that relatively low biodegradation efficiency was achieved. Also multiply of the dyes in the solution decreases process effectivity [94]. In another study, cellulose modified by diethylaminoethanol formed diethylaminoethyl-cellulose (DEAE-cellulose)was used by Cienska et al. for immobilization of tyrosinase. The authors report that tyrosinase immobilized on modified cellulose exhibited good storage stability and great reusability, and could be used in five subsequent catalytic cycles without loss of the initial activity. Moreover, after binding to the polysaccharide support, the negative effect of the toxic mixture component was strongly limited and the catalytic properties of the enzyme were retained at a high level [96]. Firooz and his team have also modified cellulose surfaces 
for covalent immobilization of tyrosinase. They used commercially available sheets of Whatman paper and immersed the sheets in a solution of ethylenediamine or propylenediamine to introduce amine groups. Laccase immobilized on amine-functionalized cellulose paper exhibited even higher catalytic activity - over $150 \%$ of that of free enzyme under optimal $\mathrm{pH}(7.0)$ and temperature $\left(35^{\circ} \mathrm{C}\right)$ conditions. Although immobilized laccase is characterized by lower substrate affinity (higher value of Michaelis-Menten constant) than free enzyme, it still seems to be a very promising biocatalyst for degradation of dihydroxyphenylalanine (L-DOPA) [93]. It should be stated that other forms of cellulose such as cellulose beads or cellulose beads modified by carboxyl groups (carboxymethyl cellulose) may also be used for immobilization of polyphenol oxidases. The resulting systems could be further used for degradation of phenolic compounds and synthetic dyes, with efficiencies of over $90 \%$ [95].

\subsubsection{Other biopolymers}

Other biopolymers, mainly polysaccharides, may also be used for immobilization of laccases. A broad range of materials, including agarose, $\kappa$-carrageenan, gum Arabic and other natural products such as coconut fibers or wood sawdust, can be used as support for oxidoreductase immobilization $[97,98,115]$. These materials are known for their biocompatibility and high affinity for peptides, which makes them useful for many practical applications, including industrial processes with immobilized enzymes. Gioia and co-workers applied thiolsulfinateagarose for reversible covalent immobilization of laccase from Trametes villosa. The great advantage of this support material is that after enzyme inactivation using a reducing agent like dithiothreitol (DTT), the biomolecules can be easily removed from the support surface and the matrix can be used for the next cycle of immobilization. Presented results indicated that after $24 \mathrm{~h}$ of the process at $22{ }^{\circ} \mathrm{C}$ and $\mathrm{pH} 4.8$, it would likely be possible to remove over $80 \%$ of Remazol Brilliant Blue R from textile industry effluents [97]. In another study, Cristovao et al. used green coconut fiber modified by 3-glycidoxypropyl-trimethoxysilane for immobilization of laccase at $\mathrm{pH} 7$ for one-point and at $\mathrm{pH} 10$ for multipoint covalent immobilization. Comparison of the systems so obtained showed that conducting the process under neutral $\mathrm{pH}$ resulted in production of biocatalyst with higher activity and affinity to the substrates. Both biocatalytic products were used for decolorization of reactive textile dyes such as Reactive Black 5 and Reactive Blue 114. Over $90 \%$ of the dyes could be degraded in the solution through use of the laccase-coconut fiber system [99]. 


\subsubsection{Synthetic polymers}

Besides many different organic materials of natural origin, synthetic polymers of different sizes and shapes are also used for immobilization of laccases, tyrosinases and peroxidases. Due to the presence of many functional moieties in the structure of synthetic polymers, the creation of relatively strong interactions has been observed between the enzymes and the support. Polymers can be formed into various shapes that are tailored to enzymes and products according to the particular immobilization application. Additionally, due to their structure and high stability, synthetic polymers usually protect biomolecules against degradation and enhance their stability. One of the most frequently used polymeric supports for environmental enzymes is polyvinyl alcohol (PVA). PVA is rich in hydroxyl groups, and is a strongly hydrophilic material which may be easily modified to achieve a suitable enzymatic matrix. For instance, PVA was used as fibers, beads or microspheres for covalent immobilization of horseradish peroxidase and for entrapment and encapsulation of laccase [100-102]. Chhabra and his team entrapped laccase from Cyathus bulleri in polyvinyl alcohol beads for degradation of azo-dyes in a continuous packed column. The biocatalytic system they thus obtained, in addition to retaining high activity (over 90\%), was characterized by good storage stability $\left(70 \%\right.$ after 5 months of storage at $4{ }^{\circ} \mathrm{C}$ ) and reusability (over $90 \%$ of initial activity after 5 days of the process). Continuous batch decolorization in a packed bed bioreactor under optimal conditions led to nearly 90\% decolorization of Acid Violet 17, Basic Green 4 and Acid Red 27 [102]. Other common synthetic polymers might also be useful for enzyme immobilization. Laccases and tyrosinases of different origin as well as lignin or manganese peroxidases could be immobilized mainly by encapsulation or covalent immobilization through use of polyacrylamide hydrogel, polyacrylonitrile beads, poly-Nvinylpyrrolidone or epoxy activated polyethersulfone beads. The produced biocatalytic systems have been utilized for various environmental applications, but these systems are most commonly applied for degradation of phenol and its derivatives and to allow selected removal of environmental contaminants at relatively high efficiencies. For example, Nicolucci et al. applied tyrosinase immobilized on polyacrylonitrile beads to eliminate bisphenol A, B, F and tetracholorobisphenol A. In a degradation process carried out in bed reactor, a degradation of over $90 \%$ was obtained for each of the tested endocrine disruptor [104]. In study by Shesterenko and co-workers, tyrosinase from Agaricus bisporus was immobilized on poly-Nvinylpyrrolidone and used for removal of phenol. After $1 \mathrm{~h}$ of the process at $25{ }^{\circ} \mathrm{C}$, total degradation of phenol was observed [105]. Polyamide in the form of a nylon membrane has also been applied for immobilization of polyphenol oxidases. This solution not only increases 
stability of the immobilized enzyme and permits continuous use of the immobilized oxidase, but also limits inhibition of the biocatalyst due to easy separation of the product from the reaction mixture. Nylon membrane with loaded enzyme was used for continuous biodegradation of phenol and its derivatives carried out in a bioreactor; the system has potential as a biocatalyst for biotransformation of phenols or bioremediation of phenolpolluted water [108]. Supports based on polymeric resins have been used to achieve multisubunit or multipoint immobilization of enzymes. Application of multipoint immobilization is required as its usually prevents biomolecule structure from denaturation, inactivation and structural damage and therefore helps to maintain catalytic activity at a high level. However, on the other hand might also leads to creation of diffusional limitations due to the blocking of enzymes active sites. Thus, Satoh et al. used a commercially available anionexchange resin for covalent immobilization of mushroom tyrosinase. The immobilized enzyme exhibited high catalytic properties and stability under reaction conditions as well as reusability, as indicated by almost unaltered enzyme activity after five repeated catalytic cycles. Furthermore, a column-packed reactor with immobilized tyrosinase was used for effective degradation of $p$-cresol and allowed its removal at an efficiency of around $80 \%$. To achieve higher effectivity of reactor, additional hydrogen peroxide supply must be ensured, that is the main limitation of the presented concept [110].

According to the references presented above it can be concluded that application of organic support materials for enzymes used for environmental decontamination is quite popular. The great advantage of these materials is that they can be used in different shapes (particles fibers), forms (membranes, beads and sizes). For instance, nylon membrane, fibers obtained from green coconut and chitosan microspheres was applied for covalent immobilization of polyphenol oxidase, laccase from Aspergillus and lignin peroxidase from Coriolus versicolor, respectively and used for removal of various pollutants, like $p$-cresol, Reactive Black 5 or even waste waters after molasses conversion [77,99,108]. Biocatalytic systems obtained, irrespectively of the applied form of support material, allowed degradation of over $80 \%$ of hazardous compounds. As it was also presented above, alginate-based materials were employed for entrapment of i.e. tyrosinase from Streptomyces espinosus, manganese peroxidase from G. lucidum BL05 or horseradish peroxidase and used for degradation of natural reactive dyes, phenol or pyrogallol $[80,82,87]$. Obtained removal efficiencies that exceed $75 \%$ proved versatility of these materials as the support could be used for immobilization of different enzymes and applied for removal of various contaminants. On the one hand the great variety of the enzymes could be immobilized, but on the other hand high 
diffusional limitations and leakage of the biomolecules from the support limit higher biodegradation efficiencies.

It could be concluded that using organic support for immobilization of oxidoreductases, there is some freedom in selection of attachment technique, because all above-mentioned immobilization protocols, that could be applied results in production of immobilized enzymes characterized by improved thermal, chemical and operational stability. Biocatalytic systems based on the organic matrices are employed for degradation of a very large number of environmental pollutants, ranging from synthetic and natural dyes, through phenol and its derivatives, to more complex compounds like pharmaceuticals. However, compared to the synthetic polymers, application of biopolymers have received wider consideration over the recent years. Several factors can justify this fact. Among others, the presence of many functional groups, ability to form various geometrical structures that increase protection of enzymes against the reaction conditions, biocompatibility, abundance in nature and fact that they are renewable should be enumerated. We believe that even though biopolymers, such as chitosan, alginates or cellulose are commonly used as a carriers for enzyme immobilization, these materials still have a great potential which can be used to develop a multidisciplinary approach covering the areas of biocatalysis, environmental protection and bioprocess engineering.

\subsection{Inorganic materials}

Besides the many organic materials presented above, inorganic supports are also widely used for immobilization of enzymes for environmental applications. Inorganic materials are suitable for enzyme immobilization due to their exceptional mechanical and chemical stability and electrical properties and are known for their large specific surface area, which may even be up to $1000 \mathrm{~m}^{2} / \mathrm{g}$ for silica SBA 15 [116], porous structure, and controllable nanometer sizes similar to that of enzyme molecules [117,118]. The great advantage of inorganic supports in comparison to other materials is that they can be obtained relatively cheaply and simply due to their abundant presence and usually non-complicated synthesis procedure.Moreover, the presence of many hydroxyl, carbonyl and carboxyl groups on the surface of the inorganic carriers causes easier enzyme attachment and facilitates support functionalization through the use of surface modifying agents like glutaraldehyde or 3aminpropyltriethoxysilane (APTES) [119]. Thus, inorganic materials are commonly used for immobilization of laccases, tyrosinase and phenoloxidases. Selected examples of the various inorganic materials of different origins and their application for immobilization of laccases, 
tyrosinases and lignin, manganese and phenol oxidases to biodegrade environmental pollutants are presented in Table 3 , followed by discussion.

\section{Table 3}

\subsubsection{Silicas}

Silica in various forms and sizes is the most commonly used inorganic support material for immobilization of oxidoreductases for environmental protection. It should be stressed that the hydrophilic character of the silica surface as well as presence of many hydroxyl groups on its surface leads to immobilization of biomolecules not only via adsorption [125] but also by creation of covalent bonds [123,127] and even by encapsulation [131]. Special attention should be paid to multiplicity of forms of silica which could be exploited for immobilization. For example, mesoporous, ordered silica at pore sizes of $14.1 \mathrm{~nm}$ was used for immobilization of lignin peroxidase from Phanerochaete chrysosporium. The resulting product was used for degradation of Acid Orange II and removed over $75 \%$ of the dye from water solution [122]. In another study, Nair and co-workers used mesoporous silica spheres with a high surface area for covalent attachment of laccase from Coriolopsis gallica using glutaraldehyde as crosslinking agent. The biocatalytic system thus produced was characterized by high catalytic activity (over $380 \mathrm{U} / \mathrm{g}$ ) and allowed for effective biodegradation of bisphenol A, diclofenac and 17- $\alpha$-ethinylestradiol at efficiencies of over $70 \%$ for each compound [124]. Laccase from Cerrena unicolor has been covalently immobilized via glutaraldehyde on the surface of silica beads at control porosity with a pore size at around $375 \AA$ A. Immobilized enzyme was more active than its free form over a wide $\mathrm{pH}$ range from 4 to 9 and at temperatures of up to $70{ }^{\circ} \mathrm{C}$. The resulting systems were used for elimination of $80 \%$ of bisphenol A, $40 \%$ of nonylphenol, and $60 \%$ of triclosan from water solution [129]. An interesting example of use of a silica matrix for immobilization of enzymes was presented by Sani et al. In their study, they used semi-transparent and fluffy powder of silica aerogel with a surface area of around $600 \mathrm{~m}^{2} / \mathrm{g}$ for encapsulation of tyrosinase. The structure of the matrix strongly reduced diffusional limitation in transport of the substrates and as a result helped to retain high catalytic activity by the immobilized biomolecules. Furthermore, leakage of tyrosinase from the carrier was reduced by its encapsulation in the silica matrix which also protected tyrosinase from harsh reaction conditions. This effects resulted in reusability of the produced system, which after 10 repeated degradation cycles still retained over $70 \%$ of the initial catalytic properties. The biocatalytic system was used for degradation of phenol in water solution. After $3 \mathrm{~h}$ of 
biodegradation under optimal conditions $\left(\mathrm{pH} \mathrm{7,30}{ }^{\circ} \mathrm{C}\right)$, over $90 \%$ of the pollutant was removed [131]. In summary, oxidoreductases have thus been immobilized on various types of silica supports and applied for biodegradation of a several organic compounds ranging from phenol and its derivatives, and endocrine disrupting chemicals, to synthetic and natural dyes, with high efficiencies, usually over $80 \%$. However, it also should be noticed that the limitation of the silica-based materials is fact that whit out surface modification, usually adsorption immobilization occurred. This results in enzyme leakage and decrease in catalytic properties.

\subsubsection{Inorganic oxides}

Besides silica, other inorganic oxides such as titania, zinc oxide, alumina and magnetic iron (II,III) oxide are also used for immobilization of enzymes for environmental applications due to the presence of many functional groups, mainly hydroxyl and carbonyl groups. These materials are known from their high surface area and defined porosity that enhance attachment of a large amount of enzyme and increase catalytic activity of the produced systems. The abovementioned materials are characterized by thermal, chemical and mechanical resistance, which in comparison with free enzyme significantly extends the tolerated $\mathrm{pH}$ and temperature ranges over which immobilized enzyme exhibits high catalytic activity. For instance, laccase covalently immobilized on alumina pellets exhibited over $80 \%$ of its catalytic activity at $\mathrm{pH} 4$ to 6 and from at temperature from 35 to $60{ }^{\circ} \mathrm{C}$. By contrast, free laccase exhibited its maximum activity only at $\mathrm{pH} 4$ and temperatures of $35-45^{\circ} \mathrm{C}$ [126]. Another advantage of the inorganic oxides is that they can be used in various morphological forms. Hou and co-workers used titania nanoparticles for adsorption immobilization of laccase from Trametes versicolor and degradation of 2,4-dichlorophenol and 2,6dimethoxyphenol. The produced biocatalytic systems, besides increases in thermal and chemical stability, seemed to be effective tools for biodegradation of disubstituted phenol derivatives. At pH 3.5 and $25{ }^{\circ} \mathrm{C}$, over $85 \%$ of 2,4-dichlorophenol and over $60 \%$ of 2,6dimethoxyphenol were removed from water solution [133]. In this study higher degradation rates were achievable due to the sorption of the phenols on the nanoparticles. In consequence, actives sites are overloaded by the substrate molecules and catalytic efficiency decreases. In recent years magnetite has become a very promising support material for enzymes due to its magnetic properties and easy separation of the produced biocatalytic systems from the reaction mixture using external magnetic fields. For instance, Balaji et al. used this material for covalent binding of laccase using glutaraldehyde and further for decolourization of water 
solution by removal of Reactive Green 19A dye. According to the presented results, over $75 \%$ of the dye was removed by using the described biocatalytic system. Moreover, use of magnetic particles for laccase immobilization significantly increased reusability of the biocatalytic system and facilitated control of the technological process [138].

\subsubsection{Minerals}

Inorganic materials such as minerals are also used for immobilization of oxidoreductases. The biggest advantage of these materials is that they are abundant in nature and inexpensive. They offer high surface areas, the presence of various functional moieties, high sorption capacity and stiffness as well as high thermal stability and resistance against mechanical destruction [151]. Various minerals, for example halloysite, kaolin, clays or bentonite could might be used for immobilization of laccases and peroxidases. Due to good resistance of these supports, irrespectively of the material used, the produced biocatalytic systems are characterized by increase in their stability in comparison to free enzyme and are known for their great reusability. For instance, Chao and co-workers used halloysite nanotubes modified by dopamine for effective covalent immobilization of laccase from Trametes versicolor. The support material exhibited high loading ability to enzyme binding which facilitated the attachment of almost $170 \mathrm{mg}$ of the peptide on $1 \mathrm{~g}$ of the support. This biocatalytic system was used for biodegradation of 2,4-dichlorophenolin waste water. Under optimal operational conditions, laccase bound to halloysite nanotubes was able to remove over $90 \%$ of the pollutants in $10 \mathrm{~h}$ [139]. In another study, horseradish peroxidase was immobilized by adsorption on the surface of aluminum-pillared interlayered clay for the treatment of wastewater polluted with phenolic compounds. After immobilization, the system exerted a perfect removal of phenol products over a broader $\mathrm{pH}$ range of 4.5 to 9.3 than the free biocatalyst was able to achieve. Furthermore, addition of polyethylene glycol to the wastewater was shown to significantly enhance phenol removal efficiency while reducing the amount of immobilized enzyme required to achieve a removal efficiency of over $90 \%$ [142].

\subsubsection{Carbon-based materials}

Special attention should be paid to carbon-based materials from among the very wide range of inorganic materials used for immobilization of enzymes for environmental applications. Carbon-based materials are considered as a valuable support for enzyme immobilization because they have well-developed porous structures with pores of various size or volume and high specific surface areas (up to $1000 \mathrm{~m}^{2} / \mathrm{g}$ ), which means that these materials have a large 
number of contact sites on their surface for enzyme immobilization [152]. Carbon-based materials are also characterized by the presence of many functional groups on their surface [153]. Single-walled and multi-walled carbon nanotubes are those mostly used for covalent immobilization of laccases and tyrosinases. Carbon nanotubes could significantly enhance the electron transfer rate between substrates and laccase and as a consequence increase the catalytic activity of the immobilized biomolecules. Additionally, through the creation of relatively strong chemical interactions between enzyme and support, carbon nanotubes increase the stability of the immobilized biomolecule towards harsh reaction conditions and enhance its reusability. In addition to carbon nanotubes, other materials such as carbon nanospheres or mesoporous carbon materials may also be used for immobilization of horseradish peroxidase or laccase [146,147]. Subrizi and his team used multi-walled carbon nanotubes functionalized by poly(diallyldimethylammonium chloride) for covalent immobilization of tyrosinase from Agaricus bisporus. The obtained biocatalytic systems were used for degradation of phenol in aqueous media and achieved removed of over $85 \%$ of phenol after $24 \mathrm{~h}$ of the process. It should be noted that immobilized tyrosinase was also able to catalyse removal of phenol derivatives of complicated chemical structure that react only to a small extent with the native enzyme [145]. Another example of carbon-based materials for laccase immobilization is fullerene $\mathrm{C}_{60}$. It was used by Pang et al. for covalent immobilization of laccase from Trametes versicolor and applied for degradation of bisphenol A and catechol in water solution. Though immobilized laccase, due to creation of diffusional limitations, exhibited lower affinity to the substrate (higher value of Michaelis-Menten constant), it could still be used for efficient degradation of the pollutants under mild reaction conditions [148]. As the above-mentioned materials exhibited a great variety of advantages, it should be considered that their synthesis and production is usually complex and expensive.

\subsubsection{Other inorganic materials}

It should be added that other inorganic materials such as porous glass, calcium carbonate and noble metals can also be used for oxidoreductase immobilization. Due to inertness, large surface area and electronic properties which provide good electron transfer between the enzyme and a substrate, noble metals such as gold can be used for enzyme immobilization for environmental protection. Moreover, through the use of glass nanoparticles, biomolecules can be attached to the support homogeneously and retain their rigidity and catalytic activity [154]. Qiu et al. used nanoporous gold particles with pores of diameter around $40 \mathrm{~nm}$ for adsorption immobilization of lignin peroxidase from Phanerochaete chrysosporium. Gold-bounded 
enzyme retained over two times higher catalytic activity than free enzyme after incubation for $2 \mathrm{~h}$ at $\mathrm{pH} 5$ and $45^{\circ} \mathrm{C}$. The resulting biocatalytic system was used for degradation of fuchsine, rhodamine B and pyrogallol red and removed over $75 \%$ of each compound [150]. Highly viscous liquids such as porous glass was used as beads for adsorption immobilization of laccase from Trametes versicolor. The obtained biocatalytic system, which was characterized by high thermal stability, was used in a recirculating packed or fluidized bed reactor for decolorization of textile dyes like Reactive Blue 19, Dispersed Blue 3, Acid Blue 74, Acid Red 27 and Reactive Black 5. After 30 min treatment in a fluidized bed reactor at pH 5 and 23 ${ }^{\circ} \mathrm{C}$, over $80 \%$ of the Dispersed Blue 3 and Acid Blue 74 were removed from textile industry wastewater [149]. The limitation in this this study was the adsorption binding of the enzyme, as in the recirculation mode of the reactor it caused leakage of the laccase from the support.

As has been clearly shown, various inorganic materials including inorganic oxides (mainly silica or titanium dioxide), minerals, noble metals and carbon based materials, such as singleand multi-walled carbon nanotubes, are the most commonly used for immobilization of oxidoreductases for environmental applications. For example, laccase was covalently immobilized onto the surface of alumina pellets and multi-walled carbon nanotubes without any additional cross-linker [137,145]. Produced immobilized enzymes were applied for degradation of Reactive Black 5 and Reactive Blue 19 with removal efficiencies exceed 85\% and showed great reusability. These materials are known for their thermal and $\mathrm{pH}$ stability, mechanical resistance and good operational stability. Some attention should also be paid to the possibility of reuse of selected inorganic compounds after enzyme deactivation as a result of their high stability. Following immobilization on the surface of inorganic compounds, the range of $\mathrm{pH}$ and temperature over which the immobilized enzymes could effectively be used is often extended. For instance, laccase from Trametes versicolor or Coriolopsis polyzona was immobilized onto the surface of titania nanoparticles, porous glass beads or fumed silica, respectively $[127,133,149]$. Obtained systems were used for degradation of phenol derivatives and reactive dyes over a broad range $\mathrm{pH}$ from 3.5 up to 7.5 that confirmed stabilization of enzyme structure in both, acidic and base conditions. It also should be added that inorganic support materials, due to their presence in nature or easy preparation method are relatively inexpensive, which increases their application possibilities. According to the studies reviewed above, biocatalytic systems for removal of toxic compounds produced on the basis of inorganic supports bring highly efficient biodegradation of endocrine disruptor chemicals or dyes. To support this statement it could be presented, that various fungal laccases, immobilized onto the surface of nanoporous, mesoporous and sol-gel silica were applied for 
degradation of 2,4-dinitrophenol, 2,4,6-trichlorophenol, bisphenol A, diclofenac or triclosan $[121,123,128]$. It should be emphasized that silica is very versatile support material as each of the produced biocatalytic system degraded over $85 \%$ of the contaminant.

Factors such as high stability, mechanical resistance, the presence of many functional groups, mainly hydroxyl, and abundance in nature caused that inorganic materials as supports for oxidoreductases are commonly used for environmental applications. Enzymes may be effectively attached to these materials principally mainly via adsorption immobilization due to the good sorption properties of these carriers. However, the creation of covalent bonds due to the presence of many functional groups, should not be excluded, which results in creation of stable and reusable biocatalytic systems. It has been shown that that immobilized oxidoreductases could be applied in large scale processes for effective remediation of wastewater contaminated with toxic pollutants. However, in our opinion some operational parameters still needs an improvement. Even so, due to the enhanced sensitivity and selectivity of the enzymes after immobilization using for instance noble metals or materials that enhance transfer of the electrons, biocatalytic systems containing oxidoreductases could be soon applied not only for environmental protection, but also in biosensors to detect even trace amounts of various compounds in effluents from industry or in human body fluids.

\subsection{Hybrid materials}

As previously mentioned, composite and hybrid materials as supports for enzymes have attracted researchers' attention over the last two decades. A combination of the properties of their precursors maximizes the benefits of these materials and makes them suitable supports for enzymes for many practical environmental applications. Many components of both organic and inorganic origin have been combined to create new supports for immobilization of oxidoreductases. Increases in stability and reusability of the immobilized enzyme can be achieved by the use of these types of matrices. Hybrid/composite support materials also protect biomolecules against denaturation and loss of the bioactivity under reaction conditions. Moreover, the properties of these support materials are usually designed for selected enzymes and the technological process in which the product will be applied after immobilization. An additional advantage of these materials is that due to their properties they can be applied in all immobilization techniques [155]. Selected examples of the various hybrid and composite materials used for immobilization of enzymes for environmental pollutants degradation are presented in Table 3,followed by comments. 


\section{Table 4}

\subsubsection{Inorganic-inorganic hybrid materials}

With regards to inorganic materials, mainly inorganic oxides such as silica or zinc and titanium oxide are used to produce hybrid supports for oxidoreductase immobilization. Other oxides, minerals, carbon-based materials and noble metal ions are also frequently involved in the design of the new supports. Inorganic-inorganic hybrids are usually characterized by inertness, resistance against harsh reaction conditions and good mechanical stability. As a result, the immobilized enzyme also possesses improved thermal and chemical stability and its structure is protected by the composite matrix from denaturation [181]. A great advantage of inorganic-inorganic hybrids is that they may be used in a wide variety of shapes and sizes, such as nanoparticles, nanowires, fibers, tubes and even as membranes $[159,160,192]$. Sun et al. used macroporous $\mathrm{SiO}_{2} / \mathrm{ZnO}$ nanowires modified by diethylene glycol diglycidyl ether for covalent immobilization of horseradish peroxidase. The immobilized enzyme exhibited high activity in decolorization of azo dyes, like Acid Blue 113 and Acid black 10 BX, and removed as much as 95 and $90 \%$ of these dyes, respectively. The support-bonded enzyme was able to remove over $90 \%$ of the selected dye from a solution containing dye at over $50 \mathrm{mg} / \mathrm{L}$ after less than $1 \mathrm{~h}$. Furthermore, storage stability and reusability of the immobilized biomolecule was significantly improved in comparison with the free enzyme [156]. Special attention, though, among others inorganic materials should also be paid to magnetic particles representing by i.e. magnetite. Biocatalytic systems based on hybrids incorporating magnetic particles may be easily separated from reaction mixtures by an external magnetic field. Magnetite particles for immobilization of laccases and removal of phenol derivatives have been combined with silica particles or mesoporous carbon material [161,164]. Superparamagnetic nanoparticles were successfully deposited on graphene oxide sheets by ultrasound-assisted co-precipitation by Chang and his team. Synthesized material was then used for immobilization of horseradish peroxidase and applied for batch biodegradation of 2chlorophenol, 4-chlorophenol and 2,4-dichlorophenol. On the one hand, removal efficiency was strongly affected by the number and position of electron-withdrawing substituents in the phenol ring, but on the other hand also lack of proper hydrogen peroxide supplying limit high removal rates. Nevertheless, the highest removal efficiency, over $80 \%$, was observed for 2chlorophenol. The results presented by these authors suggest that storage stability and tolerance to changes in temperature and $\mathrm{pH}$ of the immobilized biomolecules were better than for the free biomolecules [163]. 


\subsubsection{Inorganic-organic hybrid materials}

Though magnetite is often combined with inorganic moieties, it can be also mixed with organic materials such as biopolymers, for example chitosan or alginates $[166,175]$ as well as synthetic polymers like poly(p-phenylenediamine) or poly(4-vinyl pyridine) $[184,185]$. In a bench study magnetite nanoparticles were combined with chitosan to increase the bioaffinity of the hybrid and with clay to increase stability and mechanical resistance of the hybrid. The produced material was applied for covalent immobilization of laccase from Trametes versicolor. In comparison to the free enzyme, the immobilized biomolecules exhibited improved storage stability and better tolerance to changes in $\mathrm{pH}$ and temperature, and retained over $70 \%$ of initial activity after 10 repeated cycles. This biocatalytic system was then used for phenol degradation. After $4 \mathrm{~h}$ of treatment under optimal conditions, about $80 \%$ of phenol was removed from solution [165]. In another study, highly biocompatible chitosan core alginate capsules were enriched by magnetite nanoparticles and used for encapsulation of mushroom tyrosinase. The biomagnetic capsules thus obtained showed great storage stability, faster removal rate and greater reproducibility. This biocatalytic system could be applied for remediation of phenol and bisphenol A from real environmental water samples, because after $39 \mathrm{~h}$ of treatment of this process, $100 \%$ and over $85 \%$, respectively, of the two pollutants were degraded [174]. In work by Bayramoglu and co-workers, synthetic polymer-poly(4-vinyl pyridine) was grafted on magnetic nanoparticle beads. Next, the polymer was chelated by $\mathrm{Cu}$ (II) ions for adsorption immobilization of laccase from Trametes versicolor and enhancement of the catalytic activity of the enzyme. The biocatalyst thus produced was used in an enzyme reactor for degradation of three textile dyes - Reactive Green 19, Reactive Red 2 and Reactive Brown 10 - in a batch system. The described results show that immobilized laccase could successfully remove the three test dyes from water solution at efficiencies of 64 , 88 and $91 \%$, respectively. However, as the main factor that limit the decolorization rate was the chemical structure and type of substitute group of the dye molecules [184]. Biopolymers can also be combined with other inorganic materials to create suitable supports for immobilization of enzymes for environmental applications. For instance, chitosan was mixed with silica or cesium oxide, minerals or glass beads $[169,170,172]$, while alginate was combined with silica gel [176]. An interesting example of the creation of inorganic-organic hybrids was presented by Dincer and co-workers. They mixed clay with chitosan and crosslinked hybrid material by glutaraldehyde to form beads that were used for covalent immobilization of tyrosinase. The authors reported high enzyme activity and loading 
efficiency due to the presence of many functional groups in the structure of the support. The immobilized tyrosinase was used for degradation of phenol in water solution. After treatment for $6 \mathrm{~h}$ at $25^{\circ} \mathrm{C}$ and $\mathrm{pH} 7$, all of the phenol was removed. The biocatalytic system was able to retain over $50 \%$ of its initial activity after seven repeated tests [171]. In this study achievement of the better reusability was limited by the inhibition and inactivation of the enzymes over consecutive catalytic cycles. Besides biopolymers, synthetic polymers may also be combined with inorganic components to form suitable matrices for immobilization of enzymes for environmental protection. For instance, poly(2-chloroethyl acrylate) was combined with zeolite particles, as latex hydrogel was mixed with graphene oxide to formed nanobeads. Both hybrids were then used for immobilization of laccase and applied for degradation of textile dyes with high efficiencies [180,182]. Xu et al. used mesoporous $\mathrm{SiO}_{2}$ nanofibers and connected them with poly(acrylic acid). Finally, the hybrid system was modified by vinyl groups to increase its affinity for laccase. The synthesized matrix was characterized by a mesoporous structure (pore size 1.73-3.54 $\mathrm{nm}$ ) and a high specific surface area $\left(542.91 \mathrm{~m}^{2} / \mathrm{g}\right)$ which allowed covalent bonding of about $420 \mathrm{mg}$ of the enzyme per $1 \mathrm{~g}$ of the support. The immobilized biomolecule exhibited better storage stability and higher tolerance to harsh $\mathrm{pH}$ and temperature conditions in comparison with free laccase. The biocatalytic system, after $2 \mathrm{~h}$ of triclosan treatment, under optimal process conditions $(\mathrm{pH} 4$, $30{ }^{\circ} \mathrm{C}$ ) removed around $65 \%$ of the pollutant from water solution [181]. The factor that limit degradation efficiency might be an enzyme overloading, which blocked active sites of the biocatalysts and decrease their activity.

\subsubsection{Organic-organic hybrid materials}

When there is a need for materials with more sophisticated features such as special reactive functional groups or unusual shape, polymers can be fixed with biopolymers or other synthetic polymer. Synthesized organic-organic hybrids due to the presence of biopolymers, such as calcium or sodium alginate, are biocompatible and non-toxic, because the presence of the polymers such as poly(acrylamide-crotonic acid) or polyvinyl alcohol ensures stability, mechanical resistance and stiffness of the hybrid support [177,178]. Polyamide 6/chitosan nanofibers modified by using two different spacers (bovine serum albumin and hexamethylenediamine) have been used for immobilization of laccase from Trametes versicolor and applied for biodegradation of endocrine disrupting chemicals like bisphenol A and 17- $\alpha$-ethinylestradiol. The resulting biocatalytic systems proved to be efficient not only in removal of a mixture of the pollutants ( $92 \%$ of bisphenol A removal, total degradation of 17 - 
$\alpha$-ethinylestradiol) but also showed great reusability. After three treatment cycles, the initial activity of this system was unaltered [179]. It should also be mentioned that hybrid supports built from two synthetic polymers may be used for immobilization of various oxidoreductases. Synthetic polymer hybrids are formed by polymerization using various monomers with desired properties. These materials exhibit chemical and mechanical stability and possess many desirable functional groups and are characterized by a large specific surface area that allows a great number of biomolecules to be attached in a stable way mainly via covalent bonds. For example, horseradish peroxidase was immobilized on composite poly(vinyl alcohol)/4-hydroxybenz-aldehyde cinnamate or poly(styrene-co-methacrylic acid) nanofibers [186,190]. The produced biocatalytic systems were applied for degradation of phenol derivatives and were able to remove over $80 \%$ of the pollutants from water solution. But the limitation of the presented biocatalytic system was covalent binding of the molecules and in disruption in the structure of the enzyme active sites. In another study, Uygun and coworkers used poly(methyl methacrylate-co-glycidyl methacrylate) cryogel for immobilization of laccase from Trametes versicolor and degradation of textile dyes effluent. The immobilized enzyme degraded up to $80 \%$ of the selected dye with degree of degradation dependent on the chemical structure and molecular mass of the pollutants [189]. Sathishkumar et al. applied poly(lactic-co-glycolic acid) nanofibers for covalent immobilization of laccase from Pleurotus florida. The obtained biocatalytic system was used for biodegradation of diclofenac from aqueous sources. The results the authors present demonstrated that the environmental pollutant could be completely transformed into non-hazardous compounds. Moreover, their biocatalytic system exhibited great reusability. After three reuse cycles diclofenac was completely removed. Additionally, after addition of syringaldehyde, reusability of the system was extended to six catalytic cycles. The immobilized laccase had better storage, $\mathrm{pH}$ and thermal stability than the free biocatalyst [187]. It should be also noted that when synthetic polymer hybrids are used, entrapment also takes place. For this reason poly(acryl-amide) gel was used for entrapment of manganese peroxidase from Ganoder malucidum IBL-05. The immobilized enzyme exhibited good storage stability and could retain over $50 \%$ of initial activity after storage for two months at $4{ }^{\circ} \mathrm{C}$. The thermal stability of the immobilized peroxidase was also significantly improved. After incubation for $72 \mathrm{~h}$ at $50^{\circ} \mathrm{C}$, the enzyme retained over $40 \%$ of its initial properties while the free biomolecule was completely inactive. The immobilized catalyst was further used for removal of textile dyes from real water solutions [188]. 
As has been clearly demonstrated various types of hybrids and composite materials can be applied for immobilization of enzymes for remediation of parlous pollutants. It is becoming more and more common to use these materials due to the possibility of designing their properties to fulfill the requirements of the technological process and of the enzyme. Precursor materials may be chosen to protect of the enzyme structure, increase thermal and chemical resistance of the immobilized biomolecules as well as to improve their catalytic properties. For example, carbon nanotubes could enhance transfer of the electron during catalytic reaction as the addition of $\mathrm{Cu}^{2+}$ ions in general increases the catalytic activity of the oxidoreductases. For example, copper ions were incorporated into the structure of tetraaminophthalocyanine/magnetic nanoparticles and poly(4-vinyl pyridine)/magnetic beads. Hybrid supports were further used for covalent and adsorption immobilization of laccase from Pycnoporuss anguineus and Trametes versicolor, respectively. Produced immobilized enzymes were applied for degradation of 2,2'-azinobis-(3-ethylbenzothiazoline-6-sulphonic acid) and reactive dyes and allowed total removal of pollutants from water solution $[184,186]$. Presented examples proved that addition of inorganic ions into the structure of polymeric matrix could significantly improve removal efficiency. Other precursor materials are chosen in order to improve operational control of the remediation process. For instance, magnetic nanoparticles make separation of the immobilized enzyme from reaction mixture fast and simple as inorganic oxides ensure high mechanical stability of the biocatalytic system and its reusability. Application of the hybrid supports for enzymes and their use in bioremediation of environmental pollutants, such as phenol and its derivatives, dyes and even estrogens from wastewater, results in high efficiency of the removal process. Pollutants like 2,4dichlorophenol was efficiently removed by laccase covalently immobilized on silica magnetic particles and $\mathrm{Cu}^{2+} /$ silica magnetic particles $[159,160]$ as organic dye Reactive Green 19 was degraded with efficiencies exceed $65 \%$ by laccase from Trametes versicolor immobilized on poly(4-vinyl pyridine)/Cu(II) magnetic beads or poly(methyl methacrylate-co-glycidyl methacrylate) cryogel [184,189]. Undesirable compounds are effectively transformed into non-hazardous products, under mild conditions, whilst immobilized enzymes retain their high catalytic activity over repeated reaction cycles. Hybrids and composite materials can be formed into the shape that will be most suitable for the process. Therefore all techniques of immobilization may be used for immobilization of laccases of various origins, and for tyrosinases or peroxidases. However, note should be stated that proper selection of the immobilization technique is required to avoid diffusional limitations and enzyme inactivation. Hybrid support of inorganic-inorganic, organic-organic and mixed inorganic-organic origin, 
like magnetic nanoparticles/graphene oxide nanocomposite, chitosan/polyacrylamide hydrogel and alginate/ $\mathrm{SiO}_{2}$ gel were applied for covalent immobilization of horseradish peroxidase, encapsulation of laccase from Trametes versicolor and entrapment of polyphenol oxidase, respectively $[163,173,176]$. Immobilized enzymes were then used for degradation of phenol and its derivatives and organic dyes with removal efficiencies around $80 \%$ that proved versatility of the hybrid materials. However, higher degradation rate is limited by the diffusional limitations of reaction mixture.

Irrespectively of the origin of precursors, properties of the hybrid and composites materials could be tailored to meet the requirements of the enzymes and the process, making these materials particularly interesting as support for immobilization. Therefore, we strongly suggest more advanced research related to the application of the above-mentioned materials as a carriers for oxidoreductases which should result in formation of active biocatalytic systems for removal of hazardous compounds with high efficiencies despite the fact that they are expensive and methodology for their synthesis is usually complicated. We also believe that hybrid and composite materials has continued to grow during recent years, as these materials are also particularly interesting in terms of potential for further exploitation. In the near future, hybrid and composite supports materials could be used for immobilization of enzymes for production of highly sensitive biosensors, as well as for efficient, more specific and "cleaner" catalysts in chemicals synthesis, or might even find application in clinical medicine. It should be mentioned that hybrids materials could be also used as an efficient and stable support for co-immobilization of enzymes and application of the resulting biocatalytic systems in multienzymatic bioconversion processes.

\section{Effect of support materials and immobilization technique on substrates accessibility}

As it was previously stated, laccases and tyrosinases required molecular oxygen as a substrate that is reduced to water during catalytic pathways of these enzymes [191,192]. Similarly, peroxidases ( $\mathrm{LiP}, \mathrm{MnP}, \mathrm{HRP}$ ) need hydrogen peroxide, that during reaction is also reduced to water. The catalytic mechanism of laccases, tyrosinases and peroxidases differ from each other, but accessibility of the molecular oxygen and hydrogen peroxide, beside availability of phenolic substrates, is a key factor that limits catalytic efficiency of the immobilized oxidoreductases [193,194].

To ensure high exposition of the enzyme active site for contact with substrates, proper selection of immobilization protocol has to be done. For instance, in case of adsorption immobilization by limited number of formed interactions, interference in the structure of the 
enzyme and amino acids rearrangements is reduced, as it facilitates easy binding of $\mathrm{O}_{2}$ or $\mathrm{H}_{2} \mathrm{O}_{2}$. In contrast, covalent binding of the biocatalysts usually disrupts the structure of enzyme and its catalytic site, what makes interactions with reducing substrates more difficult. Enzymes immobilized by encapsulation or entrapment are usually physically locked into the matrix that limits structural changes of the biomolecules. But on the other hand, significant diffusional limitations occurs that reduce efficient transfer of substrates and decrease catalytic activity [195]. To support this statement some examples are presented below. For instance, fungal laccases were immobilized by adsorption, covalent binding and entrapment, using supports of organic origin, and applied for degradation of reactive dyes. Acid Orange 7 was almost totally removed from water solution by adsorbed enzyme, as $80 \%$ of Reactive Yellow 15 and about $50 \%$ of Remazol Brilliant Blue R were degraded by laccase immobilized by covalent binding and entrapment, respectively [76,99,147]. Different values of removal efficiencies might be explained mainly by various immobilization strategies and related to this different diffusional limitations, which are the lowest in adsorption immobilization and the highest in encapsulation due to enzyme surrounding by the support layer. Formed diffusional limitations strongly influence accessibility of the molecular oxygen and hydrogen peroxide to the active site of the enzymes and in consequence affect effectivity of biodegradation $[196,197]$.

When the supply of the oxygen or hydrogen peroxide is hindered, mesoporous materials at highly ordered structure of pores should be use, while they enable ease penetration of the oxygen or hydrogen peroxide molecules. In consequence higher removal efficiencies might be achieved using these materials. That proves, that application of various matrix for immobilization of the same enzyme could results in different degradation values and indicates that structural composition and properties of support material affect accessibility of $\mathrm{O}_{2}$ or $\mathrm{H}_{2} \mathrm{O}_{2}$. Although most of the bioremediation processes using immobilized oxidoreductases are carried out without additional supply of reducing substrates there is a room for improvements leading to the higher robustness of the enzymes and cost reduction. For instance, some additional process like bubbling, oxygenation, aeration and even simple shaking could be applied to increase accessibility of the reducing substrates for immobilized enzymes.

\section{Summary and comparison of the support materials of various origin}

In the presented study it has been clearly shown that many various materials of organic, inorganic and hybrid/composite origin could be efficiently applied for immobilization of 
oxidoreductases for environmental application. The most important advantages and disadvantages of each type of the support materials were briefly summarized and are presented in Fig 4.

\section{Figure 4}

The multiplicity of the possible supports caused that their proper selection is strongly governed by the type of the enzyme, immobilization technique and undesirable compound that has to be removed. For instance for immobilization of laccase from Trametes versicolor, the most commonly applied oxidoreductase for environmental application, materials of different hydrophilicity and functional moieties $\left(-\mathrm{OH},-\mathrm{NH}_{2}, \mathrm{C}=\mathrm{O}\right)$ of organic, inorganic and hybrid origin, such as chitosan and polyvinyl alcohol capsules [76,101], mesoporous silica and Fullere $\mathrm{C}_{60}$ [121,148] as well as magnetic chitosan/clay beads or poly(4-vinyl pyridine $) / \mathrm{Cu}$ (II) magnetic beads $[165,184]$ were applied. Also mushroom tyrosinase was immobilized using wide range of support materials, such as cellulose paper [83], silica gel [130] and chitosan/clay and chitosan/alginate magnetic capsules [171,174]. Obtained biocatalytic systems were applied for degradation of synthetic and natural dyes and phenol and its derivatives with removal efficiencies usually higher than $80 \%$, which proves that immobilized oxidoreductases are stable, irrespectively of the origin of support material. More attention should be paid on immobilization of laccase and tyrosinase on hybrid supports, such as poly(4-vinyl pyridine)/Cu(II) magnetic beads and chitosan/alginate magnetic capsules by adsorption and encapsulation, respectively. Immobilized laccase was used for degradation of Reactive Brown 91 and removed over $90 \%$ of the dye [184] as encapsulated tyrosinase degraded about $85 \%$ of bisphenol A from water solution [174]. Presented results prove that immobilized enzymes not only retain their robustness but also might be easily separated from reaction mixture by addition of magnetic particles. That suggest that hybrid and composite materials might be interesting for immobilization of laccases and tyrosinases and their practical application on larger scale for bioremediation of pollutants. Although various supports could be used for immobilization of laccases, tyrosinases and peroxidases, during selection of the specific material for practical applications mainly its accessibility and costs of its obtaining, purification and synthesis should be taken into account. Also high stability in harsh process conditions and mechanical resistance are a crucial factors determining selection of the carrier for immobilization of oxidoreductases. As inorganic carriers and biopolymers seems to be particularly interesting from the point of view of economy and stability, hybrid 
and composites materials are outstandingly attractive because they might be tailored and produced to enhance catalytic activity of the immobilized enzymes and in consequence to improve efficiencies of the processes carried out.

As it was previously mentioned, immobilization methodology also strongly influence the selection of enzyme support. Highly porous materials, at high specific surface area facilitate adsorption immobilization and enhance attachment of greater amounts of enzyme. As an example, chitosan beads, titania nanoparticles, mesoporous carbon and silica/magnetic/methacrylyol particles should be enumerated [78,133,147,158]. These materials were used for immobilization of laccase, tyrosinase and even lignin peroxidase and applied for removal of mainly dyes and phenol from water solutions with removal efficiencies not exceeding $90 \%$. This might be related to the binding of great amount of enzyme, which might leads to biomolecules overcrowding and in consequence decrease in catalytic activity [196]. On the other hand, immobilization of oxidoreductases on materials with numerous of functional groups facilitate covalent immobilization and multipoint attachment of the enzyme molecules. That is preferred in terms of improving stability of immobilized enzyme, however might also lead to creation of diffusional limitations in transport of substrates. From that point of view, particularly interesting are hybrid materials, such as magnetic chitosan/clay beads and poly(lactic-co-glycolic acid) nanofibers that were used for covalent binding of laccase from Trametes versicolor and applied for degradation of phenol and diclofenac, respectively $[165,187]$. Even taking into account diffusional limitations, stability of the enzyme was significantly improved and allow total removal of phenol and diclofenac from the tested solution. Inorganic materials such as mesoporous silica spheres and halloysite nanotubes $[124,139]$ and organic carriers of natural origin like chitosan or coconut fibers could be applied for covalent immobilization [75,99]. The above-mentioned supports were used for immobilization of all reviewed oxidoreductases and applied for biodegradation of synthetic and natural dyes, pharmaceuticals and phenols usually with efficiencies exceeding $80 \%$. However, it should be emphasized that inorganic and organic materials for covalent attachment of the enzyme usually require intermediate agents, such as glutaraldehyde, that facilitate creation of covalent bonds. For immobilization of oxidoreductases also encapsulation and entrapment are applied. As supports for these techniques of immobilization mainly alginates-based materials are adapted due to their remarkable abilities for gelation under mild conditions and high operational stability [78-91]. Also poly vinyl alcohol beads, silica aerogel and hybrid chitosan/polyacrylamide hydrogel were used for encapsulation of laccases and tyrosinases [102,131,173]. For instance laccase was immobilized by 
encapsulation into chitosan beads and by entrapment into copper alginate beads and they were applied for degradation of Indigo carmine [79,91]. Both biocatalytic systems allowed total degradation of the dye, but addition of copper ions into alginate beads increased activity of the laccase and caused that degradation process was four times shorter and was carried out in milder temperature conditions $\left(30^{\circ} \mathrm{C}\right)$ as compared to chitosan beads $\left(37^{\circ} \mathrm{C}\right)$. It is our belief that among the existing immobilization protocols, two approaches are of particular interest. Firstly, immobilization of oxidoreductases in the way where interference in the enzyme structure is highly limited as it results no conformational changes in the biocatalysts structure and retention of high catalytic properties. The second approach is a multipoint immobilization of the enzyme. As a result biomolecule is permanently attached to the support material that results in the improvement of the reusability of the immobilized biocatalysts. However, we would like to emphasize that selection of the most suitable immobilization protocol is governed mainly by the type of the support and practical requirements for the biocatalytic system.

Irrespectively of the origin, support materials could be applied for biodegradation of the same type of the persistent pollutants. For instance, fungal laccases covalently immobilized using mesoporous silica and polyamide/chitosan composite [123,179] as well as mushroom tyrosinase immobilized by entrapment using silica alginate and by covalent binding on polyacrylonitrile beads $[85,104]$ were applied for remediation of bisphenol A. Removal efficiencies ranging from $80 \%$ (mesoporous silica) up to $92 \%$ (composite support) were noticed for immobilized laccase as for tyrosinase it was 35\% (silica alginate) and 90\% (hybrid support). On the other hand, synthetic dyes could be efficiently removed by oxidoreductases immobilized using wide range of support materials. For example, for remediation of synthetic dye Remazol Brilliant Blue R, laccase immobilized by covalent binding on gum Arabic and graphene oxide/latex hydrogel and encapsulated into magnetic $\mathrm{Cu}$ alginate beads were applied $[97,175,182]$. The remediation efficiencies varied from $80 \%$ (gum Arabic) to $100 \%$ (hybrid material) for covalently immobilized enzyme. In case of encapsulated laccase, mainly due to the occurrence of diffusional limitations, biodegradation efficiency reached $76 \%$ and even a presence of copper ions in the support material did not improve performance of the process. These data clearly shows that porosity of the support material, type of surface functional groups and immobilization technique strongly affect degradation process of bisphenol A and Remazol Brilliant Blue R. 
Many studies from research laboratories show promising early stage proof-of-concept results for application of oxidoreductases for environmental application, however, they suffer because there is a significant lack of work targeting the whole chain including production costs of the immobilized enzymes, any scale-up advantages of manufacturing of matrices and biocatalytic systems, as well as presenting their storage stability and practical implementation. Also broader comparison of several different types of immobilized enzyme systems, for example laccase systems that have broad substrate selectivity, are warranted. Presented studies and their limitations show that the time is now ripe for moving to the next level of multidisciplinary assessment and there is a need to involve the companies and environmental agencies in the research as they should help to overcome various practical limitations. As the results of these studies we should obtain immobilization protocols allowing production of universal biocatalytic systems for degradation and remediation of hazardous pollutants.

\section{General summary and remarks}

In recent years, environmental pollutants such as synthetic and natural dyes, pharmaceuticals and phenol and its derivatives have become a very serious problem that needs to be solved to minimize the direct threats posed by these compounds to the health and life of living organisms. One possible way to remove hazardous contamination from wastewater and soils is their biodegradation using enzymes. It has been shown that phenyloxidase enzymes, such as laccase, tyrosinase or lignin, manganese and horseradish peroxidases, as a members of oxidoreductase catalytic class, may catalyse oxidation and transformation of numerous persistent compounds into non-toxic derivatives. These processes were usually carried out without addition of cofactors or mediators except molecular oxygen or hydrogen peroxide, which are widely available. The studies reviewed here can lead to a better understanding of enzymatic biodegradation and illustrate the following benefits of oxidoreductase enzymes:

(i) biodegradation processes may be carried out in highly efficient way under mild conditions,

(ii) removal of environmental contaminants is possible without use of toxic solvents or high energy consumption, in accordance with the rules of green chemistry,

(iii) remediation of pollutants may usually be carried out in more cost-effective way, without the need for advanced equipment,

(iv) conversion of hazardous compounds into their non-toxic derivatives may be achieved. 
Despite the many promising results, it is evident that more research is needed to clarify the levels of different pollutants and residual pharmaceuticals locally, particular near industrial area and near hospitals. Next, a much better understanding of the competitive kinetics of different substrates on enzymatic removal by oxidoreductases, such as laccases or tyrosinases is clearly missing. Lastly, durability and robustness of different types of enzymes in genuine application environments should be assessed. This review also shows the need for larger comparative application trial among different types of enzymatic options for removal of pharmaceutical residues in particular.

It should further be pointed out that the immobilization process is frequently applied to increase stability of the enzymes and enhance their reusability as well as to create insoluble biocatalyst that may be reused. Here we have summarized and reviewed materials and their properties that could be used as supports in immobilization of enzymes for environmental applications. As we have described, materials of both organic and inorganic origin as well as hybrids and composites supports have been be applied for immobilization of oxidoreductases. We have also reported the key factors that determine selection of the support for immobilization of enzymes for contaminants removal as being the following:

(i) the presence of numerous functional groups for effective enzyme binding,

(ii) good sorption properties,

(iii) good thermal and chemical resistance and mechanical and operational stability.

However, materials with desired properties that increase activity and stability of the immobilized biocatalysts have also been examined. Furthermore, we have summarized the possible ways to perform the biodegradation processes and possibilities for increasing their efficiency.

Thus, our aim has been to review support materials that may be applied for immobilization of enzymes for environmental applications and show how these materials affect catalytic activity and stability of the biocatalysts. We wanted to present criteria for selection of support materials to produce biocatalytic systems which have excellent catalytic properties and good stability for use in modern remediation of undesirable pollutants from domestic and industrial wastewaters. Information presented in this review could form a basis for evaluation of a novel, highly efficient detoxification process conducted under mild conditions, without utilization of a hazardous reagents, in accordance with the rules of green chemistry.

While applications of immobilized laccases have been well studied, only few previous studies have dealt with the efficient use of other oxidoreductases for environmental 
protection. The information displayed on this review confirms that tyrosinases, and peroxidases such as horseradish, manganese and lignin peroxidase show promise as efficient treatments for removal of hazardous pollutants after immobilization, even at industrial scale. The main challenge to this respect is to build systems able to operate in continuous mode, so the operational costs of such bioremediation processes can be reduced. Additionally, further studies on the role of these enzymes on the removal of other compounds such as hormones or antibiotics will have to be also addressed in future studies.

\section{Acknowledgements:}

This work was supported by research grant funds from the National Science Center Poland in accordance with decision no. DEC-2016/20/T/ST8/00391. 


\section{References}

[1] Ning B, Graham N, Zhang Y, Nakonechny M, El-Din MG, Ozone: Science and Engineering, 2007; 29: 153.

[2] Rezg R, El-Faza S, Gharbi N, Mornagui B, Environment International, 2014; 64: 83.

[3] Barrios-Estrada C, de Jesús Rostro-Alanis M,Muñoz-Gutiérrez BD,Iqbal HMN,Kannan S, Parra-Saldívar R, Science of the Total Environment, 2018; 612: 1516.

[4] Bilal M, Asgher M, Iqbal HMN, Hu H, Zhang X, Environmental Science and Pollution Research, 2017; 24: 7035.

[5] Tiwari D, Kamble J, Chilgunde S, Patil P, Maru G, Kawle D, Bhartiya U, Joseph L, Vanage G, Mutation Research, 2012; 743: 83.

[6] Rochester JR, Reproductive Toxicology, 2013; 42: 132.

[7] Cowan DA, Fernandez-Lafuente R, Enzyme and Microbial Technology, 2011; 49: 326.

[8] Arora PK, Kumar M, Chauhan A, Raghava GP, Jain RK, BMC Res Notes, 2009; 2 vol. 2, Article number 67.

[9] Sanchez-Ferrer A, Rodriguez-Lopez JN, Garcia-Canovas G, Garcia-Camona V, Biochimica et BiophysicaActa - Protein Structure and Molecular Enzymology, 1995; 1247: 1 .

[10] Kalyani DC, Munk L, Mikkelsen JD, Meyer AS, RSC Advances, 2016; 6: 3910.

[11] Demarche P, Junghanns C, Nair RR, Agathos SN, Biotechnology Advances, 2012; 30: 933.

[12] Zhao H, Journal of Chemical Technology and Biotechnology, 2010; 85: 891.

[13] Zhang Y, Ge J, Liu Z, ACS Catalysis, 2015; 5: 4503.

[14] Iyer PV, Ananthanarayan L, Process Biochemistry, 2008; 43: 1019.

[15] Bilal M, Iqbal HMN, Guo S, Hu H, Wang W, Zhang X, International Journal of Biological Macromolecules, 2018; 108: 893.

[16] Krajewska B, Zaborska W, Leszko M, Journal of Molecular Catalysis B: Enzymatic, 1997; 3: 231.

[17] Ba S, Arsenault A, Hassani T, Jones JP, Cabana H, Critical Reviews in Biotechnology, 2013; 33: 404.

[18] Mateo C, Abian O, Bernedo M, Cuenca E, Fuentes M, Fernandez-Lorente G, Palomo JM, Grazu V, Pessela BCC, Giacomini C, Irazoqui G, Villarino A, Ovsejevi K, BatistaViera F, Fernandez-Lafuente R, Guisán JM, Enzyme and Microbial Technology, 2005; 37: 456 . 
[19] Barbosa O, Torres R, Ortiz C, Berenguer-Murcia A, Rodrigues RC, Fernandez-Lafuente R, Biomacromolecules, 2013; 14: 2433.

[20] Mateo C, Grazu V, Palomo JM, Lopez-Gallego F, Fernandez-Lafuente R, Guisan JM, Nature Protocols, 2007; 2: 1022.

[21] Rao M, Scelza R, Acevedo F, Diez MC, Gianfreda L, Chemosphere, 2014; 107: 145.

[22] Bilal M, Asgher M, Parra-Saldivar R, Hu H, Wang,W, Zhang X, Iqbal HMN, Science of the Total Environment, 2017; 576: 646.

[23] Ba S, Haroune L, Cruz-Morato C, Jacquet C, Touahar IE, Bellenger JP, Legault CY, Jones JP, Cabana H, Science of the Total Environment, 2014; 487: 748.

[24] Cha J, Kim T, Choi J, Jang K, Khaleda L, Kim W, Jeon J, Journal of Agricultural and Food Chemistry, 2017; 65: 1167.

[25] Bronikowski A, Hagedoorn PL, Koschorreck K, Urlacher VB, AMB Express, 2017; 73: 1.

[26] Abdel-Hamind AM, Solbiati JO, Cann IKO, Advances in Applied Microbiologyl, 2013; 82: 1 .

[27] Giardina P, Faraco V, Pezzella C, Piscitelli A, Vanhulle S, Sannia G, Cellular and Molecular Life Sciences, 2010; 67: 369.

[28] Mogharabi M, Faramarzi MA, Advanced Synthesis \& Catalysis 2014; 356: 897.

[29] Le TT, Murugesan K, Lee CS, Vu CH, Chang YS, Jeon JK, Bioresource Technology, 2016; 216: 203

[30] Barrios-Estrada C, Rostro-Alanis MJ, Parra AL, Belleville MP, Sanchez-Marcano J, Iqbal HMN, Parra-Saldívar R, International Journal of Biological Macromolecules, 2018; $108: 837$.

[31] Tagger S, Perissol C, Gil G, Vogt G, Le Petit J, Enzyme and Microbial Technology, 1998; 23: 372.

[32] Fukuda T, Uchida H, Suzuki M, Miyamoto H, Morinaga H, Nawata H, Uwajima T, Journal of Chemical Technology and Biotechnology, 2004; 79: 1212.

[33] Yang J, Lin Y, Yang X, Ng TB, Ye X, Lin J, Journal of Hazardous Materials, 2016; 322: 525 .

[34] Olivares C, Solano F, Pigment Cell Melanoma Research, 2009; 22: 750.

[35] Selinheimo E, NiEidhin D, Steffensen C, Nielsen J, Lomascolo A, Halaouli S, Record E, O’Beirne D, Buchert J, Kruus K, Journal of Biotechnology, 2007; 130. 471.

[36] Land CA, Ramsden PA, Riley PA, Accounts of Chemical Research, 2003; 36: 300. 
[37] Shuster V, Fishman A, Journal of Molecular Microbiology and Biotechnology, 2009; 17: 188 .

[38] Faccio G, Kruus K, Saloheimo M, Thöny-Meyer L, Process Biochemistry, 2012; 47: 1749.

[39] Ihekata K, Nicell JA, Bioresource Technology, 2000; 74: 191.

[40] Munjal N, Sawhney SK, Enzyme and Microbial Technology, 2002; 30: 613.

[41] Blodig W, Smith AT, Doyle WA, Piontek K, Journal of Molecular Biology, 2001; 305: 851.

[42] Wong DWS, Applied Biochemistry and Biotechnology, 2009; 157: 174.

[43] Valli K, Wariishi H, Gold MH, Biochemistry, 1990; 29: 8535.

[44] Tien M, Kirt TK, Science, 1983; 221: 661.

[45] Shaheen R, Asgher M, Hussain F, Bhatti HN, International Journal of Biological Macromolecules, 2017; 103: 57.

[46] Glenn JK, Akileswaran L, Gold MH, Archives of Biochemistry and Biophysics, 1986; 251: 688 .

[47] Hofrichter M, Enzyme and Microbial Technology, 2002; 30: 454.

[48] Glenn JK, Gold MH, Archives of Biochemistry and Biophysics, 1985; 242: 329.

[49] Bonnarme P, Jeffries TW, Applied Environmental Microbiology, 1990; 56: 210-217.

[50] Yehia RS, Rodriguez-Couto S, Applied Biochemistry and Microbiology, 2017; 53: 222.

[51] Veitch NC, Phytochemistry, 2004; 65: 249.

[52] Haschke RH, Friedhoff JM, Biochemical and Biophysical Research Communications, 1978; 80: 1039 .

[53] Shigeoka S, Ishikawa T, Tamoi M, Miyagawa Y, Takeda T, Yabuta Y, Yoshimura K, Journal of Experimental Biology, 2002; 53: 1305.

[54] Bilal M, Rasheed T, Iqbal HMN, Hu H, Wang W, Zhang X, International Journal of Biological Macromolecules, 2018; 113: 983.

[55] Bilal M, Iqbal HMN, Shah SZH, Hu H, Wang W, Zhang X, Journal of Environmental Management, 2016;183: 836.

[56] Bilal M, Asgher M, Iqbal HMN, Hu H, Wang W, Zhang X, International Journal of Biological Macromolecules, 2017; 102: 582.

[57] Bilal M, Rasheed T, Iqbal HMN, Hu H, Wang W, Zhang X, International Journal of Biological Macromolecules, 2017; 105; 328.

[58] Chattopadhyay K, Mazumdar S, Biochemistry, 2000; 39: 263.

[59] Jesionowski T, Zdarta J, Krajewska B, Adsorption, 2014; 20: 801. 
[60] Garcia-Galan C, Berenguer-Murcia A, Fernandez-Lafuente R, Rodrigues RC, Advanced Synthesis \& Catalysis, 2011; 353: 2885.

[61] Dicosimo R, McAuliffe J, Poulose AJ, Bohlmann G, Chemical Society Reviews, 2013; 42: 6437.

[62] Reetz MT, Journal of the American Chemical Society, 2013; 135: 12480.

[63] Adlercreutz P, Chemical Society Reviews, 2013; 42: 6406.

[64] Guzik U, Hupert-Kocurek K, Wojcieszynska D, Molecules, 2014; 19: 8995.

[65] Krasnan V, Stloukal R, Rosenberg M, Rebroš M, Applied Microbiology and Biotechnology, 2016; 100: 2535.

[66] Spahn C, Minteer SD, Recent Patents on Engineering, 2008; 2: 195.

[67] Hernandez K, Fernandez-Lafuente R, Enzyme and Microbial Technology, 2011; 48: 107.

[68] Mateo C, Palomo JM, Fernandez-Lorente G, Guisan JM, Fernandez-Lafuente R, Enzyme and Microbial Technology, 2007; 40: 1451.

[69] Cao L, Current Opinion in Chemical Biology, 2005; 9: 217.

[70] Brady D, Jordaan J, Biotechnology Letters, 2009; 31: 1639.

[71] Sheldon RA, Advanced Synthesis \& Catalysis, 2007; 349: 1289.

[72] Sheldon RA, Organic Process Research \& Development, 2011; 15: 213.

[73] Mukherjee S, Basak B, Bhunia B, Dey A, Mondal B, Reviews in Environmental Science and Bio/Technology, 2013; 12: 61.

[74] Ba S, Kumar VV, Critical Reviews in Biotechnology, 2017; 37 :819.

[75] Zhang J, Liu X, Xu Z, Chen H, Yang Y, International Biodeterioration\& Biodegradation, 2008; 61: 351 .

[76] Zheng F, Cui BK, Wu XJ, Meng G, Liu HX, Si J, International Biodeterioration\& Biodegradation, 2016; 110: 69.

[77] Ran Y, Zhifeiche X, Chen W, Applied Mechanics and Materials, 2012; 138-139: 1067.

[78] Sofia P, Asgher M, Shahid M, Randhawa MA, Journal of Animal and Plant Sciences, 2016; 26: 1451

[79] Jaiswal N, Pandey VP, Dwived UN, International Journal of Biological Macromolecules, 2016; 86: 288.

[80] Bilal M, Asgher M, BMC Biotechnology, 2015; 15: 111.

[81] Romanovskaya II, Shesterenko YA, Sevastyanov OA, Brusilovskii IE, Journal of Water Chemistry and Technology, 2010; 32: 61. 
[82] Roy S, Das I, Munjal M, Karthik L, Kumar G, Kumar S, Rao KVB, Frontiers in Biology, 2014; 9: 306.

[83] Narayanan PM, Murugan S, Eva AS, Devina SU, Kalidass S, Research Journal of Microbiology, 2015; 10: 421.

[84] Kampmann M, Boll S, Kossuch J, Bielecki J, Uhl S, Kleiner B, Wichmann R, Water Research, 2014; 57: 295.

[85] Kampmann M, Hoffrichter AC, Stalinski D, Wichmann R, Journal of Molecular Catalysis B: Enzymatic, 2015; 116: 124.

[86] Usluoglu A, Arabaci G, Research Journal of Chemistry and Environment, 2013; 17: 16.

[87] Spasojević D, Prokopijevic M, Prodanović O, Pirtea MG, Radotić K, Prodanović R, , HemijskaIndustrija, 2014; 68: 117.

[88] Daassi D, Rodríguez-Couto S, Nasri M, Mechichi T, International Biodeterioration\& Biodegradation, 2014; 90: 71.

[89] Sanlier SH, Gider S, Köprülü A, Artificial Cells, Nanomedicine, and Biotechnology, $2013 ; 41: 259$.

[90] Kocaturk S, Yagar H, Artificial Cells, Blood Substitutes and Biotechnology, 2010; 38: 157.

[91] Phetsom J, Khammuang S, Suwannawong P, Sarnthima R, Journal of Biological Sciences, 2009; 9: 573.

[92] Loncar N, Božić N, Anđelković I, Milovanović A, Dojnov B, Vujčić M, Roglić G, Vujčić Z, Journal of the Serbian Chemical Society, 2011; 76: 513.

[93] Firooz NS, Panahi R, Mokhtarani B, Yazdani F,Cellulose, 2017; 24: 1407.

[94] Sathishkumar P, Kamala-Kannan S, Cho M, Kim JS, Hadibarata T, Salim MR, Oh BT, Journal of Molecular Catalysis B: Enzymatic, 2014; 100: 111.

[95] Arica MY, Polymer International, 2000; 49: 775.

[96] Cienska M, Labus K, Lewańczuk M, Koźlecki T, Liesiene J, Bryjak J, PLoS One, 2016; 11: 1 .

[97] Gioia L, Rodriguez-Couto S, del Pilar Menendez M, Manta C, Ovsejevi K, Biotechnology and Applied Biochemistry, 2014; 87: 502.

[98] Jadhav SW, Singhal RS, International Biodeterioration\& Biodegradation, 2013; 85: 271.

[99] Cristovao RO, Silverio SC, Tavares APM, Brigida AIS, Loureiro JM, Boaventura RAR, Macedo EA, Coelho MAZ, World Journal of Microbiology and Biotechnology, 2012; 28: 2827 . 
[100]Rodriguez-deLuna SE, Moreno-Cortez IE, Garza-Navarro MA, Lucio-Porto R, Pavon LL, Gonzalez-Gonzalez VA, Journal of Applied Polymer Science, 2017; 134: 1.

[101] Stloukal R, Watzková J, Gregušová B, Chemical Papers, 2014; 68: 1514.

[102]Chhabra M, Mishra S, Sreekrishnan TR, Journal of Environmental Health Science \& Engineering, 2015; 13: 38.

[103] Gassara F, Brar SK, Verma M, Tyagi RD, Chemosphere, 2013; 92: 1356.

[104]Nicolucci C, Rossi S, Menale C, Godjevargova T, Ivanov Y, Bianco M, Mita L, Bencivenga U, Mita DG, Diano N, Biodegradation, 2011; 22: 673.

[105] Shesterenko YA, Sevastyanov OV, Romanovskaya II, Journal of Water Chemistry and Technology, 2012; 34: 107.

[106]Dogan T, Bayram E, Uzun L, Senel S, Denizli A, Trametes versicolor laccase immobilized poly(glycidyl methacrylate) based cryogels for phenol degradation from aqueous media, Journal of Applied Polymer Science, 2015; 132: 1.

[107]Misra N, Kumar V, Goel NK, Varshney L, Polymer, 2014; 55: 6017.

[108]Burton SG, Boshoff A, Edwards W, Rose PD, Journal of Molecular Catalysis B: Enzymatic, 1998; 5: 411.

[109]Peralta-Zamora P, Gomes de Moraes S, Esposito E, Antunes R, Reyes J, Durán N, Decolorization of pulp mill effluents with immobilized lignin and manganese peroxidase from Phanerochaetechrysosporium, Environmental Technology, 1998; 19: 521.

[110] Satoh E, Tamura A, Kawagoe J, Ichimura Y, Nishi K, Yamada K, KobunshiRonbunsyu, 2008; 65: 104.

[111]Li Z, Shang W, Liu W, Li H, Desalination and Water Treatment, 2014; 52: 2594.

[112] Gombotz WR, Wee SF, Protein release from alginate matrices, Advanced Drug Delivery Reviews, 1998; 31: 267.

[113]Lee KY, Mooney DJ, Progress in Polymer Science, 2012; 37: 106.

[114]Feng Q, Hou D, Zhao Y, Xu T, Menkhaus TJ, Fong H, ACS Applied Materials and Interfaces, 2014; 6: 20958.

[115]Makas YG, Kalkan NA, Aksoy S, Altinok H, Nesrin NH, Journal of Biotechnology, 2010; 148: 216

[116]Thielemann JP, Girgsdies F, Schlögl R, Hess C, Beilstein Journal of Nanotechnology, 2011; 2: 110.

[117]Bapat G, Labade C, Chaudhari A, Zinjarde S, Advances in Colloid and Interface Science, 2016; 237: 1. 
[118]Carlsson N, Gustafsson H, Thörn C, Olsson L, Holmberg K, Åkerman B, Advances in Colloid and Interface Science, 2014; 205: 339.

[119]Zucca P, Sanjust E, Molecules, 2014; 19: 14139.

[120]Bautista LF, Morales G, Sanz R, Bioresource Technology, 2010; 101: 8541.

[121]Dehghanifard E, Jafari AJ, Kalantary RR, Mahvi AH, Faramarzi MA, Esrafili A, Iranian Journal of Environmental Health Science \& Engineering, 2013; 10: 25.

[122]Hu Z, Xu L, Wen X, Journal of Environmental Sciences, 2012; 25: 181.

[123]Debaste F, Songulashvili G, Penninckx MJ, Desalination and Water Treatment, 2014; 52: 2344 .

[124] Nair RP, Demarche P, Agathos SN, New Biotechnology, 2013; 30: 814.

[125]Xu LQ, Wen XH, Ding HJ, Environmental Science, 2010; 31: 2493.

[126]McHedlishvili NI, Pruidze GN, Omiadze NT, Zukhbaya RV, PrikladnayaBiokhimiyaiMikrobiologiya, 2000; 36: 141.

[127]Hommes G, Gasser CA, Howald CB, Goers R, Schlosser D, Shahgaldian P, Corvini PF, Bioresource Technology, 2012; 115: 8.

[128]Qiu L, Huang Z, World Journal of Microbiology and Biotechnology, 2010; 26: 775.

[129]Songulashvili G, Jimenez-Tobon GA, Jaspers C, Penninckx MJ, Fungal Biology, 2012; 116: 883 .

[130] Seetharam GB, Saville BA, Water Research, 2003; 37: 436.

[131]Sani S, Muhid MNM, Hamdan H, Journal of Sol-Gel Science and Technology, 2011; 59: 7.

[132]Bayramoglu G, Akbulut A, Arica MY, Journal of Hazardous Materials, 2013; 244-245: 528.

[133]Hou J, Dong G, Ye Y, Chenn V, Journal of Membrane Science, 2014; 452: 229.

[134]Mohajershojaei K, Mahmoodi NM, Khosravi A, Biotechnology and Bioprocess Engineering, 2015; 20: 109.

[135]Zhang Y, Wu H, Huang X, Zhang J, Guo S, Nanoscale Research Letters 2011; 6: 450.

[136]Singh N, Basu S, Vankelecom IFJ, Balakrishna M, Applied Biochemistry and Biotechnology 2015; 177: 76.

[137]Abadulla E, Tzanov T, Costa S, Robra KH, Cavaco-Paulo A, Gubitz GM, Applied and Environmental Microbiology, 2000; 66: 3357.

[138]Balaji N, Kumar KS, Seenuvasan M, Vinodhini G, Kumar MA, Journal of Environmental Biology, 2016; 37: 1489. 
[139]Chao C, Liu J, Wang J, Zhang Y, Zhang B, Zhang Y, Xiang X, Chen R, ACS Applied Materials and Interfaces, 2013; 5: 10559.

[140]Sekuljica N, Prlainovic ZZ, Jovanovic JR, Stefanovic AB, Djokic VR, Mijin DZ, Knezevic-Jugovic ZD, Bioprocess and Biosystems Engineering, 2016; 39: 461.

[141] Acevedo F, Pizzul L, Castillo MdP, González ME, Cea M, Gianfreda L, Diez MC, Chemosphere, 2010; 80: 271.

[142]Cheng J, Yu SM, Zuo P, Water Research, 2006; 40: 283.

[143] Oliveira SF, Rodrigues da Luz JM, Kasuya MCM, Ladeira LO, Junior AC, Saudi Journal of Biological Sciences, DOI: doi.org/10.1016/j.sjbs.2016.02.018.

[144] Othman AM, Gonzalez-Dominguez E, Sanroman A, Correa-Duartec M, Moldes D, RSC Advances, 2016; 6: 114690 .

[145] Subrizi F, Crucianelli M, Grossi V, Passacantando M, Pesci L, Saladino R, ACS Catalysis, 2014; 4: 810.

[146]Lu YM, Yang QY, Wang LM, Zhang MZ, Guo WQ, Ca ZN, Wang DD, Yang WW,

Chen Y, Clean - Soil, Air, Water, 2017; 45: 1600077.

[147]Ramírez-Montoya LA, Hernández-Montoya V, Montes-Morán MA, Jáuregui-Rincón J, Cervantes FJ, Journal of Molecular Liquids, 2015; 212: 30."

[148]Pang R, Li M, Zhang C, Talanta, 2015; 131: 38.

[149]Champagne PP, Ramsay JA, Bioresource Technology, 2010; 101: 2230.

[150]Qiu H, Li Y, Ji G, Zhou G, Huang X, Qu Y, Gao P, Bioresource Technology, 2009; 100: 3837.

[151]Lvov, Y, Aerov A, Fakhrullin R, Advances in Colloid and Interface Science, 2014; 207, 189.

[152]Daoud FBO, Kaddour S, Sadoun T, Colloid and Surfaces B: Biointerfaces, 2010; 75: 93.

[153]Zhang C, Luo S, Chen W, Talanta, 2013; 113: 142.

[154]Delvaux M, Demoustier-Champagne S, Biosensors and Bioelectronics, 2003; 18: 943.

[155]Ge J, Lei J, Zare RN, Nature Nanotechnology, 2012; 7: 428.

[156]Sun H, Jin X, Long N, Zhang R, International Journal of Biological Macromolecules, 2017; 95: 1049 .

[157]Li ZL, Cheng L, Zhang LW, Liu W, Ma WQ, Liu L, Process Safety and Environmental Protection, 2017; 107: 463.

[158]Lin J, Lai Q, Liu Y, Chen S, Le X, Zhou X, International Journal of Biological Macromolecules, 2017; 102: 144. 
[159]Wang Y, Chen X, Liu J, He F, Wang R, Environmental Science and Pollution Research, 2013; 20: 6222 .

[160]Huan W, Yang Y, Wu B, Yuan H, Zhang Y, Chinese Journal of Chemistry, 2012; 30: 2849.

[161]Wang F, Hu Y, Guo C, Huang W, Liu CZ, Bioresource Technology, 2012; 110: 120.

[162] Yang Y, Wei Q, Zhang J, Xi Y, Yuan H, Chen C, Liu X, Biochemical Engineering Journal, 2015; 97: 111.

[163]Chang Q, Jiang G, Tang H, Li N, Huang J, Wu L, Chinese Journal of Catalysis, 2015; 36: 961.

[164]Liu Y, Zeng Z, Zeng G, Tang L, Pang Y, Li Z, Liu C, Lei X, Wua M, Ren P, Liu Z, Chen M, Xie G, Bioresource Technology, 2012; 115: 21.

[165] Aydemir T, Guler S, Artificial Cells, Nanomedicine and Biotechnology, 2015; 43: 425.

[166]Peniche H, Osorio A, Acosta N, de la Campa A, Peniche C, Journal of Applied Polymer Science, 2005; 98: 651.

[167]Abdollahi K, Yazdani F, Panahi R, International Journal of Biological Macromolecules, 2017; 94: 396.

[168] Shao J, Ge H, Yang Y, Biotechnology Letters, 2007; 29: 901.

[169]Luan PP, Jiang YJ, Zhang SP, Gao J, Su ZG, Ma GH, Zhang YF, Journal of Bioscience and Bioengineering, 2014; 118: 575.

[170]Lin J, Fan L, Miao R, Le X, Chen S, Zhou X, International Journal of Biological Macromolecules, 2015; 78: 1.

[171]Dincer A, Becerik S, Aydemir T, International Journal of Biological Macromolecules, 2012; 50: 815 .

[172] Sadighi A, Faramarzi MA, Journal of the Taiwan Institute of Chemical Engineers, 2013; 44: 156.

[173]Sun H, Yang H, Huang W, Zhang S, Journal of Colloid and Interface Science, 2015; 450: 353.

[174]Ispas CR, Ravalli MT, Steere A, Andreescu S, Water Research, 2010; 11: 1961.

[175]Le TT, Murugesan K, Lee CS, Vu CH, Chang YS, Jeon JR, Bioresource Technology, 2016; 216: 203

[176]Shao J, Huang LL, Yang YM, Journal of Chemical Technology and Biotechnology, 2009; 84: 633.

[177]Koklukaya SZ, Sezer S, Aksoy S, Hasirci N, Biotechnology and Applied Biochemistry, 2016; 32: 699. 
[178]Bilal M, Asgher M, Chemistry Central Journal, 2015; 9, Article number 47.

[179]Maryskova M, Ardao I, García-Gonzalez CA, Martinova L, Rotkova J, Sevcu A, Enzyme and Microbial Technology, 2016; 89: 31.

[180]Celikbicak O, Bayramoglu G, Yilmaz M, Ersoy G, Bicak N, Salih B, Arica MY, Microporous and Mesoporous Materials, 2014; 199: 57.

[181]Xu R, Si Y, Wu X, Li F, Zhang B, Chemical Engineering Journal, 2015; 255: 63.

[182] Ormategui N, Veloso A, Leal GP, Rodriguez-Couto S, Tomovska R, ACS Applied Materials and Interfaces, 2015; 7: 14104.

[183]Huang J, Xiao H, Li B, Wang J, Jiang D, Biotechnology and Applied Biochemistry, 2006; 44: 93.

[184]Bayramoglu G, Yilmaz M, Arica MY, Bioresource Technology, 2010; 101: 6615.

[185]Liu Y, Yan M, Geng Y, Huang J, Applied Sciences, 2016; 6: 232.

[186]Pan C, Ding R, Dong L, Wang J, Hu Y, Journal of Nanomaterials, 2015; 2015, Article number 616879.

[187] Sathishkumar P, Chae JC, Unnithan AR, Palvannan T, Kim HY, Lee KJ, Cho M, Kamala-Kannan S, Oh BT, Enzyme and Microbial Technology, 2012; 51: 113.

[188]Bilal M, Asgher M, Iqbal HM, Protein \& Peptide Letters, 2016; 23: 812.

[189]Uygun M, Journal of Chemistry, 2013; 2013, Article ID 387181.

[190]Rojas-Melgarejo F, Rodriguez-Lopez JN, Garcia-Canovas F, Garcia-Ruiz PA, Carbohydrate Polymers, 2004; 58: 79-88.

[191]Nashar RME, Talanta, 2012; 96: 161.

[192] Shang CY, Li WX Zhang RF, Materials Research Bulletin, 2015; 68: 336.

[193] Gouveia S, Fernández-Costas C, Sanromán MA, Moldes D, Bioresource Technology, 2012; 121: 131

[194]Baldrian P, Fungal laccases - occurrence and properties, FEMS Microbiology Reviews, 2006; 30: 215.

[195]Willner I, Yan YM, Willner B, Tel-Vered R, Fuel Cells, 2009; 9: 7.

[196]Kumar S, Jana AK, Dhamija I, Singla Y, Maiti M, Europena Journal of Pharmaceuticals and Biopharmaceuticals, 2013; 85: 413.

[197] Ortner A, Huber D, Haske-Cornelius O, Weber HK, Hofer K, Bauer W, Nyanhongo GS, Guebitza GM, Process Biochemistry, 2015; 50: 1277. 
Table 1. Main immobilization techniques, their characteristic and advantages.

\begin{tabular}{|l|l|l|l|l|}
\hline Immobilization technique & $\begin{array}{l}\text { Main functional groups } \\
\text { of the support }\end{array}$ & Type of interactions & $\begin{array}{l}\text { Strength of } \\
\text { interactions }\end{array}$ & Advantages \\
\hline Non-covalent (adsorption) & $\begin{array}{l}\mathrm{NH},-\mathrm{SH},-\mathrm{OH}, \mathrm{C}=\mathrm{O}, \\
\mathrm{COOH}, \text { epoxy groups }\end{array}$ & $\begin{array}{l}\text { hydrogen bonds, } \\
\text { ionic interactions, } \\
\text { hydrophobic interactions }\end{array}$ & weak & $\begin{array}{l}\text { no enzyme modification, } \\
\text { simple and inexpensive } \\
\text { reusability of the support }\end{array}$ \\
\hline Covalent binding & $-\mathrm{NH}_{2},-\mathrm{SH},-\mathrm{OH}, \mathrm{C}=\mathrm{O}$ & covalent bonds & $\begin{array}{l}\text { strong and stable interactions, } \\
\text { multipoint attachment, } \\
\text { reducing of enzyme leakage }\end{array}$ \\
\hline Encapsulation & $-\mathrm{NH}_{2},-\mathrm{OH}$, & $\begin{array}{l}\text { strong } \\
\text { hydrophobic interactions }\end{array}$ & weak & $\begin{array}{l}\text { no enzyme modification, } \\
\text { protection of the enzyme }\end{array}$ \\
\hline Entrapment & $-\mathrm{NH}_{2},-\mathrm{OH}, \mathrm{C}=\mathrm{O}$ & $\begin{array}{l}\text { ionic interactions, } \\
\text { hydrophobic interactions, } \\
\text { covalent bonds }\end{array}$ & weak/strong & no enzyme modification, \\
\hline Cross-linking & $\mathrm{C}=\mathrm{O},-\mathrm{NH}_{2}$ & strong & $\begin{array}{l}\text { no support needed, } \\
\text { high strength of interactions }\end{array}$ \\
\hline
\end{tabular}


Table 2. Materials of organic origin used for immobilization of laccases, tyrosinases and lignin, manganese and phenols oxidases for biodegradation of various environmental pollutants.

\begin{tabular}{|c|c|c|c|c|c|c|}
\hline Support material & Enzyme & \begin{tabular}{|l|}
$\begin{array}{l}\text { Immobilization } \\
\text { technique }\end{array}$ \\
\end{tabular} & Contaminants & Process conditions & $\begin{array}{l}\text { Removal } \\
\text { efficiency }\end{array}$ & Reference \\
\hline Chitosan & $\begin{array}{l}\text { Laccase from Coriolus } \\
\text { versicolor }\end{array}$ & $\begin{array}{l}\text { Covalent } \\
\text { immobilization }\end{array}$ & $\begin{array}{l}\text { 2,4-dichlorophenol, } \\
\text { 4-chlorophenol, } \\
\text { 2-chlorophenol }\end{array}$ & $\mathrm{pH}=5.5,35^{\circ} \mathrm{C}, 24 \mathrm{~h}$ & $\begin{array}{l}94 \% \\
75 \% \\
69 \%\end{array}$ & {$[75]$} \\
\hline Chitosan & $\begin{array}{l}\text { Laccase from Trametes } \\
\text { pubescens }\end{array}$ & Entrapment & $\begin{array}{l}\text { Reactive Brilliant Blue X-BR, } \\
\text { Remazol Brilliant Blue R, } \\
\text { Congo Red, } \\
\text { Acid Black 172, } \\
\text { Methylene Blue, } \\
\text { Neutral Red, } \\
\text { Indigo Blue, } \\
\text { Naphthol Green B, } \\
\text { Direct Fast Blue FBL, } \\
\text { Crystal Violet }\end{array}$ & $\mathrm{pH}=5,50^{\circ} \mathrm{C}$, & $\begin{array}{l}55 \%, \\
50 \%, \\
55 \%, \\
70 \%, \\
25 \%, \\
45 \%, \\
45 \%, \\
40 \%, \\
60 \%, \\
20 \%\end{array}$ & {$[76]$} \\
\hline Chitosan microspheres & $\begin{array}{l}\text { Lignin peroxidase and } \\
\text { manganese peroxidase from } \\
\text { Coriolus versicolor }\end{array}$ & $\begin{array}{l}\text { Covalent } \\
\text { immobilization/ } \\
\text { cross-linking }\end{array}$ & $\begin{array}{l}\text { Decolorizing of molasses waste } \\
\text { water }\end{array}$ & $\mathrm{pH}=8.4,30^{\circ} \mathrm{C}, 6 \mathrm{~h}$ & $80 \%$ & {$[77]$} \\
\hline Chitosan beads & $\begin{array}{l}\text { Lignin peroxidase from } \\
\text { Schizophyllum commune } \\
\text { IBL-06 }\end{array}$ & $\begin{array}{l}\text { Adsorption } \\
\text { immobilization }\end{array}$ & Synthetic textile dyes & $30^{\circ} \mathrm{C}, 4 \mathrm{~h}$ & $95.5 \%$ & {$[78]$} \\
\hline Chitosan beads & Laccase from papaya & Entrapment & Indigo Carmine & $\mathrm{pH}=10,37^{\circ} \mathrm{C}, 8 \mathrm{~h}$ & $100 \%$ & {$[79]$} \\
\hline Calcium alginate & $\begin{array}{l}\text { Manganese peroxidase from } \\
\text { G. lucidum BL05 }\end{array}$ & Entrapment & Sandal tree reactive dyes & $\mathrm{pH}=4.5,35^{\circ} \mathrm{C}, 12 \mathrm{~h}$ & up to $95 \%$ & {$[80]$} \\
\hline Calcium alginate & $\begin{array}{l}\text { Tyrosinase from } \\
\text { Agaricusbisporus }\end{array}$ & Entrapment & Phenol & $\mathrm{pH}=7.2,25^{\circ} \mathrm{C}, 1 \mathrm{~h}$ & $100 \%$ & {$[81]$} \\
\hline Sodium alginate & $\begin{array}{l}\text { Tyrosinase from } \\
\text { Streptomyces espinosus }\end{array}$ & Entrapment & Phenol & $4 \mathrm{~h}$ & up to $60 \%$ & {$[82]$} \\
\hline Sodium alginate & $\begin{array}{l}\text { Laccase from Bacillus } \\
\text { subtilis MTCC } 2414\end{array}$ & Entrapment & $\begin{array}{l}\text { Orange 3R, } \\
\text { Yellow GR, } \\
\text { T-Blue }\end{array}$ & $40^{\circ} \mathrm{C}, 120 \mathrm{~h}$ & $\begin{array}{l}74 \% \\
79 \% \\
71 \%\end{array}$ & {$[83]$} \\
\hline Silica alginate & $\begin{array}{l}\text { Tyrosinase from } \\
\text { Agaricusbisporus }\end{array}$ & Entrapment & Bisphenol A & $20^{\circ} \mathrm{C}, 24 \mathrm{~h}$ & $100 \%$ & {$[84]$} \\
\hline Silica alginate & $\begin{array}{l}\text { Tyrosinase from } \\
\text { Agaricusbisporus }\end{array}$ & Encapsulation & Bisphenol A & $20^{\circ} \mathrm{C}, 0.5 \mathrm{~h}$ & $35 \%$ & {$[85]$} \\
\hline
\end{tabular}




\begin{tabular}{|c|c|c|c|c|c|c|}
\hline Alginate beads & $\begin{array}{l}\text { Polyphenol oxidase from } \\
\text { Taraxacumofficinale }\end{array}$ & Entrapment & $\begin{array}{l}\text { synthetic dyes from industrial } \\
\text { effluents }\end{array}$ & $25^{\circ} \mathrm{C}, 1 \mathrm{~h}$ & $80 \%$ & {$[86]$} \\
\hline Alginate beads & Horseradish peroxidase & Entrapment & Pyrogallol & $\mathrm{pH}=7,25^{\circ} \mathrm{C}$ & $75 \%$ & [87] \\
\hline Alginate beads & $\begin{array}{l}\text { Laccase from } \\
\text { Coriolopsisgallica }\end{array}$ & Entrapment & $\begin{array}{l}\text { Remazol Brilliant Blue R, } \\
\text { Reactive Black 5, } \\
\text { Bismark Brown R, } \\
\text { Lanaset Grey G }\end{array}$ & $\mathrm{pH}=5,30^{\circ} \mathrm{C} 24 \mathrm{~h}$ & $\begin{array}{l}90 \% \\
81 \% \\
53 \% \\
87 \%\end{array}$ & {$[88]$} \\
\hline Alginate beads & Laccase & Entrapment & Direct Blue 2 & $\mathrm{pH}=5,30^{\circ} \mathrm{C}$ & $86 \%$ & [89] \\
\hline Copper alginate beads & $\begin{array}{l}\text { Polyphenol oxidase from } \\
\text { Cynarascolymus L. }\end{array}$ & Entrapment & L-DOPA & $\mathrm{pH}=7,25^{\circ} \mathrm{C}$ & $88 \%$ & [90] \\
\hline Copper alginate beads & $\begin{array}{l}\text { Laccase from } \\
\text { Lentinuspolychrous }\end{array}$ & Encapsulation & $\begin{array}{l}\text { Remazol Brilliant Blue R, } \\
\text { Methyl red, } \\
\text { Indigo carmine, } \\
\text { Bromophenol blue }\end{array}$ & $30^{\circ} \mathrm{C}, 2.5 \mathrm{~h}$ & $\begin{array}{l}89 \%, \\
91 \% \\
100 \%, \\
86 \%\end{array}$ & {$[91]$} \\
\hline Cellulose & Polyphenol oxidase & $\begin{array}{l}\text { Adsorption } \\
\text { immobilization }\end{array}$ & $\begin{array}{l}\text { Phenol, } \\
\text { 4-chlorophenol, } \\
\text { 4-bromophenol }\end{array}$ & $\mathrm{pH}=8,5 \mathrm{~h}$ & $\begin{array}{l}20 \% \\
30 \% \\
45 \%\end{array}$ & {$[92]$} \\
\hline Cellulose paper & Tyrosinase from mushroom & $\begin{array}{l}\text { Covalent } \\
\text { immobilization }\end{array}$ & L-DOPA & $\mathrm{pH}=7,22{ }^{\circ} \mathrm{C}, 2 \mathrm{~h}$ & $70 \%$ & {$[93]$} \\
\hline Cellulose nanofibers & Laccase & $\begin{array}{l}\text { Covalent } \\
\text { immobilization }\end{array}$ & $\begin{array}{l}\text { Simulated dye effluent consist of } \\
\text { Remazol Black 5, Remazol } \\
\text { Brilliant Blue R, Remazol } \\
\text { Brilliant Violet 5R, Reactive } \\
\text { Orange } 16 \text { and Reactive Red } 120\end{array}$ & $30^{\circ} \mathrm{C}, 12 \mathrm{~h}$ & $39 \%$ & {$[94]$} \\
\hline $\begin{array}{l}\text { Carboxymethylcellulose } \\
\text { beads }\end{array}$ & Polyphenol oxidase & $\begin{array}{l}\text { Covalent } \\
\text { immobilization }\end{array}$ & L-tyrosine & $\mathrm{pH}=6.5,25^{\circ} \mathrm{C}$ & $93 \%$ & {$[95]$} \\
\hline $\begin{array}{l}\text { Diethylaminoethyl } \\
\text { cellulose }\end{array}$ & Tyrosinase from mushroom & $\begin{array}{l}\text { Covalent } \\
\text { immobilization }\end{array}$ & L-DOPA & $\mathrm{pH}=9,4 \mathrm{~h}$ & $60 \%$ & {$[96]$} \\
\hline Thiolsulfinate-agarose & $\begin{array}{l}\text { Laccase from Trametes } \\
\text { villosa }\end{array}$ & $\begin{array}{l}\text { Covalent } \\
\text { immobilization }\end{array}$ & Remazol Brilliant Blue R & $\mathrm{pH}=4.8,22^{\circ} \mathrm{C}, 24 \mathrm{~h}$ & $80 \%$ & {$[97]$} \\
\hline Gum Arabic & Laccase & $\begin{array}{l}\text { Covalent } \\
\text { immobilization }\end{array}$ & Remazol Brilliant Blue R & $\mathrm{pH}=5,40^{\circ} \mathrm{C}, 2 \mathrm{~h}$ & $81 \%$ & [98] \\
\hline Green coconut fiber & Laccase from Aspergillus & $\begin{array}{l}\text { Covalent } \\
\text { immobilization }\end{array}$ & $\begin{array}{l}\text { Reactive Black 5, } \\
\text { Reactive Blue 114, } \\
\text { Reactive Yellow 15, } \\
\text { Reactive Yellow 176, } \\
\text { Reactive Red 239, } \\
\text { Reactive Red 180 }\end{array}$ & $\mathrm{pH}=7,35^{\circ} \mathrm{C}$ & $\begin{array}{l}90 \%, \\
90 \%, \\
77 \% \\
5 \% \\
33 \% \\
35 \%\end{array}$ & [99] \\
\hline
\end{tabular}




\begin{tabular}{|c|c|c|c|c|c|c|}
\hline Polyvinyl alcohol & Horseradish peroxidase & \begin{tabular}{|l|} 
Covalent \\
immobilization \\
\end{tabular} & pyrogallol & $\mathrm{pH}=6,25^{\circ} \mathrm{C}, 1 \mathrm{~h}$ & $80 \%$ & {$[100]$} \\
\hline $\begin{array}{l}\text { Polyvinyl alcohol } \\
\text { capsules }\end{array}$ & $\begin{array}{l}\text { Laccase from Trametes } \\
\text { versicolor }\end{array}$ & Encapsulation & Saturn Blue L4G dye & $\mathrm{pH}=5.5,25^{\circ} \mathrm{C}, 24 \mathrm{~h}$ & $48 \%$ & {$[101]$} \\
\hline Polyvinyl alcohol beads & Laccase from Cyathusbulleri & Entrapment & $\begin{array}{l}\text { Acid Violet 17, } \\
\text { Basic Green 4, } \\
\text { Acid Red } 27 \\
\end{array}$ & $\mathrm{pH}=5.5,30^{\circ} \mathrm{C}$, & $\begin{array}{l}90 \%, \\
95 \% \\
90 \%\end{array}$ & {$[102]$} \\
\hline $\begin{array}{l}\text { Polyacrylamide } \\
\text { hydrogel }\end{array}$ & $\begin{array}{l}\text { Lignin peroxidase from } P \text {. } \\
\text { chrysosporium }\end{array}$ & Encapsulation & Bisphenol A & $\mathrm{pH}=5,25^{\circ} \mathrm{C}, 8 \mathrm{~h}$ & $90 \%$ & {$[103]$} \\
\hline Polyacrylonitrile beads & Tyrosinase & $\begin{array}{l}\text { Covalent } \\
\text { immobilization }\end{array}$ & $\begin{array}{l}\text { Bisphenol A, } \\
\text { Bisphenol B, } \\
\text { Bisphenol F, } \\
\text { Tetrachlorobisphenol A }\end{array}$ & $25^{\circ} \mathrm{C}, 1.5 \mathrm{~h}$ & $\begin{array}{l}92 \%, \\
93 \%, \\
94 \%, \\
91 \%\end{array}$ & {$[104]$} \\
\hline Poly-N-vinylpyrrolidone & $\begin{array}{l}\text { Tyrosinase from } \\
\text { Agaricusbisporus }\end{array}$ & $\begin{array}{l}\text { Covalent } \\
\text { immobilization } \\
\end{array}$ & Phenol & $25^{\circ} \mathrm{C}, 1 \mathrm{~h}$ & $100 \%$ & {$[105]$} \\
\hline $\begin{array}{l}\text { Poly(2-hydroxyethyl } \\
\text { methacrylate-co- } \\
\text { glycidyl methacrylate) }\end{array}$ & $\begin{array}{l}\text { Laccase from Trametes } \\
\text { versicolor }\end{array}$ & $\begin{array}{l}\text { Covalent } \\
\text { immobilization }\end{array}$ & 3,5-dinitro salicylic acid & $\mathrm{pH}=5,55^{\circ} \mathrm{C}, 2 \mathrm{~h}$ & $75 \%$ & {$[106]$} \\
\hline $\begin{array}{l}\text { Epoxy activated } \\
\text { polyethersulfone beads }\end{array}$ & $\begin{array}{l}\text { Laccase from Trametes } \\
\text { versicolor }\end{array}$ & \begin{tabular}{|l|} 
Covalent \\
immobilization \\
\end{tabular} & Acid Red 1 & $\mathrm{pH}=5,65^{\circ} \mathrm{C}, 10$ days & $88 \%$ & {$[107]$} \\
\hline Nylon membrane & $\begin{array}{l}\text { Polyphenol oxidase from } \\
\text { Agaricusbisporus }\end{array}$ & $\begin{array}{l}\text { Covalent } \\
\text { immobilization }\end{array}$ & $\begin{array}{l}\text { Phenol, } \\
\text { p-cresol, } \\
m \text {-cresol, } \\
\text { 4-chlorophenol, } \\
\text { 4-methoxyphenol }\end{array}$ & $25^{\circ} \mathrm{C}, 8 \mathrm{~h}$ & $\begin{array}{l}\text { Over } 80 \% \text { for } \\
p \text {-cresol }\end{array}$ & {$[108]$} \\
\hline $\begin{array}{l}\text { Amberlite IRA } 400 \\
\text { resin }\end{array}$ & $\begin{array}{l}\text { Lignin peroxidase from } \\
\text { Phanerochaetechrysosporium }\end{array}$ & $\begin{array}{l}\text { Adsorption } \\
\text { immobilization }\end{array}$ & Kraft E1 effluent & $\begin{array}{l}\mathrm{pH}=3 \text { and } 7,25^{\circ} \mathrm{C}, 3 \\
\mathrm{~h}\end{array}$ & $50 \%$ & {$[109]$} \\
\hline Anion-exchange resin & Tyrosinase from mushroom & \begin{tabular}{|l} 
Covalent \\
immobilization
\end{tabular} & $p$-cresol & $25^{\circ} \mathrm{C}, 72 \mathrm{~h}$ & $83 \%$ & {$[110]$} \\
\hline
\end{tabular}


Table 3. Materials of inorganic origin used for immobilization of laccases, tyrosinases and lignin, manganese and phenol oxidases for biodegradation of various environmental pollutants.

\begin{tabular}{|c|c|c|c|c|c|c|}
\hline aterial & Enzyme & $\begin{array}{l}\text { Immobilization } \\
\text { technique }\end{array}$ & Contaminants & Process conditions & $\begin{array}{l}\text { Removal } \\
\text { efficiency }\end{array}$ & $\mathbf{R e}$ \\
\hline-15 & $\begin{array}{l}\text { Laccase from Trametes } \\
\text { versicolor }\end{array}$ & $\begin{array}{l}\text { Adsorption } \\
\text { immobilization }\end{array}$ & Naphthalene & $\mathrm{pH} 4.5,5 \mathrm{~h}$ & $30 \%$ & {$[1]$} \\
\hline s silica & $\begin{array}{l}\text { Laccase from Trametes } \\
\text { versicolor }\end{array}$ & $\begin{array}{l}\text { Adsorption } \\
\text { immobilization }\end{array}$ & 2,4-dinitrophenol & $\mathrm{pH} 5,50^{\circ} \mathrm{C}, 12 \mathrm{~h}$ & $>90 \%$ & {$[12$} \\
\hline s silica & $\begin{array}{l}\text { Lignin peroxidase from } \\
\text { Phanerochaetechrysosporium }\end{array}$ & $\begin{array}{l}\text { Covalent } \\
\text { immobilization }\end{array}$ & Acid Orange II & $\mathrm{pH} 4,35^{\circ} \mathrm{C}$ & $77 \%$ & {$[1]$} \\
\hline s silica & $\begin{array}{l}\text { Laccase from Cerrena } \\
\text { unicolor }\end{array}$ & $\begin{array}{l}\text { Covalent } \\
\text { immobilization }\end{array}$ & $\begin{array}{l}\text { Bisphenol A, } \\
\text { 4-nonylphenol, } \\
\text { Triclosan }\end{array}$ & $\mathrm{pH} 5,1 \mathrm{~h}$ & $\begin{array}{l}80 \%, \\
40 \% \\
60 \%\end{array}$ & {$[1]$} \\
\hline s silica & $\begin{array}{l}\text { Laccase from } \\
\text { Coriolopsisgallica }\end{array}$ & $\begin{array}{l}\text { Covalent } \\
\text { immobilization }\end{array}$ & $\begin{array}{l}\text { Bisphenol A, } \\
\text { Diclofenac, } \\
\text { 17- } \alpha \text {-ethinylestradiol }\end{array}$ & $\mathrm{pH} 5,25^{\circ} \mathrm{C}$ & $\begin{array}{l}90 \%, \\
85 \% \\
70 \%\end{array}$ & {$[1 ?$} \\
\hline s 2D silica & Lignin peroxidase & $\begin{array}{l}\text { Adsorption } \\
\text { immobilization }\end{array}$ & Phenol & $\mathrm{pH} 5,25^{\circ} \mathrm{C}$ & $60 \%$ & {$[1]$} \\
\hline us silica & $\begin{array}{l}\text { Phenol oxidase from Mycelia } \\
\text { sterilia IBR 35219/2 }\end{array}$ & $\begin{array}{l}\text { Covalent } \\
\text { immobilization }\end{array}$ & $\begin{array}{l}\text { Phenolic compounds of the } \\
\text { green tea extract }\end{array}$ & $\mathrm{pH} 5.2,30^{\circ} \mathrm{C}$ & $45 \%$ & {$[1]$} \\
\hline $\mathrm{ca}$ & $\begin{array}{l}\text { Laccase from } \\
\text { Coriolopsispolyzona }\end{array}$ & $\begin{array}{l}\text { Covalent } \\
\text { immobilization }\end{array}$ & Bisphenol A & $\mathrm{pH} 7.5,24^{\circ} \mathrm{C}, 72 \mathrm{~h}$ & $80 \%$ & {$[1]$} \\
\hline $\mathrm{ca}$ & Rot fungi laccase & $\begin{array}{l}\text { Adsorption } \\
\text { immobilization }\end{array}$ & $\begin{array}{l}\text { 2,4-dichlorophenol, } \\
\text { 2,4,6-trichlorophenol }\end{array}$ & $25^{\circ} \mathrm{C}, 4 \mathrm{~h}$ & $\begin{array}{l}95 \%, \\
100 \%\end{array}$ & {$[1]$} \\
\hline & $\begin{array}{l}\text { Laccase from Cerrena } \\
\text { unicolor }\end{array}$ & $\begin{array}{l}\text { Covalent } \\
\text { immobilization }\end{array}$ & $\begin{array}{l}\text { Bisphenol A, } \\
\text { Nonylphenol, } \\
\text { Triclosan }\end{array}$ & $\mathrm{pH} 5,30^{\circ} \mathrm{C}$ & $\begin{array}{l}80 \%, \\
40 \% \\
60 \%\end{array}$ & {$[1]$} \\
\hline & Tyrosinase from mushroom & $\begin{array}{l}\text { Adsorption } \\
\text { immobilization }\end{array}$ & Phenol & $\mathrm{pH} 6.8,72 \mathrm{~h}$ & $58 \%$ & {$[1]$} \\
\hline el & Tyrosinase & Encapsulation & Phenol & $\mathrm{pH} 7,30^{\circ} \mathrm{C}, 3 \mathrm{~h}$ & $90 \%$ & {$[1$.} \\
\hline silica & Tyrosinase from mushroom & $\begin{array}{l}\text { Covalent } \\
\text { immobilization }\end{array}$ & $\begin{array}{l}\text { Phenol, } \\
p \text {-cresol, } \\
\text { Phenyl acetate }\end{array}$ & $\mathrm{pH} 7,35^{\circ} \mathrm{C}, 12 \mathrm{~h}$ & $\begin{array}{l}84 \%, \\
74 \%, \\
90 \%\end{array}$ & {$[1$} \\
\hline oparticles & $\begin{array}{l}\text { Laccase from Trametes } \\
\text { versicolor }\end{array}$ & $\begin{array}{l}\text { Adsorption } \\
\text { immobilization }\end{array}$ & $\begin{array}{l}\text { 2,4-dichlorophenol, } \\
\text { 2,6-dimethoxyphenol }\end{array}$ & $\mathrm{pH} 3.5,25^{\circ} \mathrm{C}$ & $\begin{array}{l}85 \% \\
63 \%\end{array}$ & {$[1$} \\
\hline oparticles & Laccase & $\begin{array}{l}\text { Adsorption } \\
\text { immobilization }\end{array}$ & $\begin{array}{l}\text { Direct Red 31, } \\
\text { Acid Blue 92, } \\
\text { Direct Green } 6\end{array}$ & $\mathrm{pH} 3,25^{\circ} \mathrm{C}, 1 \mathrm{~h}$ & $\begin{array}{l}87 \% \\
84 \% \\
83 \%\end{array}$ & {$[1]$} \\
\hline & Horseradish peroxidase & $\begin{array}{l}\text { Covalent } \\
\text { immobilization }\end{array}$ & 4-aminoantipyrine & $\mathrm{pH} 4.5,35^{\circ} \mathrm{C}$ & $>95 \%$ & {$[1$} \\
\hline ellets & Laccase & $\begin{array}{l}\text { Covalent } \\
\text { immobilization }\end{array}$ & Melanoidins & $\mathrm{pH} 4.5,28^{\circ} \mathrm{C}, 6 \mathrm{~h}$ & $47 \%$ & {$[1]$} \\
\hline llets & $\begin{array}{l}\text { Laccase from Trametes } \\
\text { hirsuta }\end{array}$ & $\begin{array}{l}\text { Covalent } \\
\text { immobilization }\end{array}$ & $\begin{array}{l}\text { Basic Red 9, } \\
\text { Reactive Blue 19, } \\
\text { Acid Blue 225 }\end{array}$ & $\mathrm{pH} 4.5,30^{\circ} \mathrm{C}$ & $\begin{array}{l}62 \%, \\
85 \%, \\
78 \%\end{array}$ & {$[1]$} \\
\hline s & Laccase & $\begin{array}{l}\text { Covalent } \\
\text { immobilization }\end{array}$ & Reactive Green 19A & $\mathrm{pH} 5,25^{\circ} \mathrm{C}$ & $75 \%$ & {$[1$} \\
\hline nanotubes & $\begin{array}{l}\text { Laccase from Trametes } \\
\text { versicolor }\end{array}$ & $\begin{array}{l}\text { Covalent } \\
\text { immobilization }\end{array}$ & 2,4-dichlorophen & $\mathrm{pH} 5,30^{\circ} \mathrm{C}, 10 \mathrm{~h}$ & $93 \%$ & {$[1$} \\
\hline & Horseradish peroxidase & $\begin{array}{l}\text { Adsorption } \\
\text { immobilization }\end{array}$ & $\begin{array}{l}\text { Pyrogallol, } \\
\text { Acid Violet } 109\end{array}$ & $\mathrm{pH} 5,24{ }^{\circ} \mathrm{C}, 1 \mathrm{~h}$ & $\begin{array}{l}70 \% \\
87 \%\end{array}$ & {$[1$} \\
\hline noclay & $\begin{array}{l}\text { Manganese peroxidase from } \\
\text { Anthracophyllum discolor }\end{array}$ & $\begin{array}{l}\text { Adsorption } \\
\text { immobilization }\end{array}$ & $\begin{array}{l}\text { Pyrene, } \\
\text { Anthracene, } \\
\text { Fluoranthene, } \\
\text { Phenanthrene }\end{array}$ & $\mathrm{pH} 4.5,35^{\circ} \mathrm{C}, 24 \mathrm{~h}$ & $\begin{array}{l}86 \%, \\
65 \%, \\
15 \%, \\
10 \%\end{array}$ & {$[12$} \\
\hline pillared & Horseradish peroxidase & Adsorption & Phenol & $\mathrm{pH} 5,25^{\circ} \mathrm{C}, 4 \mathrm{~h}$ & $>95 \%$ & {$[1$} \\
\hline
\end{tabular}




\begin{tabular}{|c|c|c|c|c|c|c|}
\hline clay & & immobilization & & & & \\
\hline otubes & $\begin{array}{l}\text { Lignin peroxidase from } \\
\text { Ganodermalucidum }\end{array}$ & $\begin{array}{l}\text { Covalent } \\
\text { immobilization }\end{array}$ & Remazol Brilliant Blue R & $\mathrm{pH} 3.5,25^{\circ} \mathrm{C}, 24 \mathrm{~h}$ & $78 \%$ & {[} \\
\hline d carbon & $\begin{array}{l}\text { Laccase from } \\
\text { Myceliophthorahermophile }\end{array}$ & $\begin{array}{l}\text { Covalent } \\
\text { immobilization }\end{array}$ & Reactive Black 5 & $\mathrm{pH} 5,25^{\circ} \mathrm{C}, 24 \mathrm{~h}$ & $84 \%$ & {[} \\
\hline d carbon & $\begin{array}{l}\text { Tyrosinase from } \\
\text { Agaricusbisporus }\end{array}$ & $\begin{array}{l}\text { Covalent } \\
\text { immobilization }\end{array}$ & Phenol & $\mathrm{pH} 7,25^{\circ} \mathrm{C}, 24 \mathrm{~h}$ & $85 \%$ & {$[1$} \\
\hline ospheres & Horseradish peroxidase & $\begin{array}{l}\text { Covalent } \\
\text { immobilization }\end{array}$ & $\begin{array}{l}\text { 2,4 dichlorophenol, } \\
\text { 4-methoxyphenol, } \\
\text { bisphenol A }\end{array}$ & $\mathrm{pH} 7,25^{\circ} \mathrm{C}, 1.5 \mathrm{~h}$ & $\begin{array}{l}95 \%, \\
99 \%, \\
52 \%\end{array}$ & {$[1$} \\
\hline $\begin{array}{l}\text { s carbon } \\
\text { shells }\end{array}$ & $\begin{array}{l}\text { Laccase from Trametes } \\
\text { versicolor }\end{array}$ & $\begin{array}{l}\text { Adsorption } \\
\text { immobilization }\end{array}$ & $\begin{array}{l}\text { Acid Orange 7, } \\
\text { Acid Blue 74, } \\
\text { Reactive Red 2, } \\
\text { Reactive Black } 5\end{array}$ & $\mathrm{pH} 6,30{ }^{\circ} \mathrm{C}, 72 \mathrm{~h}$ & $\begin{array}{l}94 \%, \\
92 \%, \\
48 \%, \\
5 \%\end{array}$ & {$[1$} \\
\hline-60 & $\begin{array}{l}\text { Laccase from Trametes } \\
\text { versicolor }\end{array}$ & $\begin{array}{l}\text { Covalent } \\
\text { immobilization }\end{array}$ & $\begin{array}{l}\text { Bisphenol A, } \\
\text { Catechol }\end{array}$ & 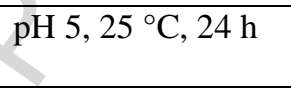 & $\begin{array}{l}23 \% \\
33 \%\end{array}$ & {$[1$} \\
\hline s beads & $\begin{array}{l}\text { Laccase from Trametes } \\
\text { versicolor }\end{array}$ & $\begin{array}{l}\text { Adsorption } \\
\text { immobilization }\end{array}$ & $\begin{array}{l}\text { Reactive Blue 19, } \\
\text { Dispersed Blue 3, } \\
\text { Acid Blue 74, } \\
\text { Acid Red 27, } \\
\text { Reactive Black } 5\end{array}$ & $\mathrm{pH} 5,23{ }^{\circ} \mathrm{C}$ & $\begin{array}{l}76 \%, \\
82 \% \\
82 \%, \\
27 \%, \\
10 \%\end{array}$ & {$[1$} \\
\hline s gold & $\begin{array}{l}\text { Lignin peroxidase from } \\
\text { Phanerochaetechrysosporium }\end{array}$ & $\begin{array}{l}\text { Adsorption } \\
\text { immobilization }\end{array}$ & $\begin{array}{l}\text { Fuchsine, } \\
\text { Rhodamine B, } \\
\text { Pyrogallol Red }\end{array}$ & $\mathrm{pH} 7,25^{\circ} \mathrm{C}, 10 \mathrm{~h}$ & $\begin{array}{l}85 \% \\
75 \% \\
87 \%\end{array}$ & \\
\hline
\end{tabular}


Table 4. Hybrid and composite support materials used for immobilization of laccases, tyrosinases and lignin, manganese and phenol oxidases for biodegradation of various environmental pollutants.

\begin{tabular}{|c|c|c|c|c|c|c|}
\hline Support material & Enzyme & $\begin{array}{l}\text { Immobilizat } \\
\text { ion } \\
\text { technique }\end{array}$ & Contaminants & $\begin{array}{l}\text { Process } \\
\text { conditio } \\
\text { ns }\end{array}$ & $\begin{array}{l}\text { Remov } \\
\text { al } \\
\text { efficien } \\
\text { cy }\end{array}$ & $\begin{array}{l}\text { Referen } \\
\text { ce }\end{array}$ \\
\hline $\begin{array}{l}\text { macroporous } \mathrm{SiO}_{2} / \\
\mathrm{ZnO} \text { nanowires }\end{array}$ & $\begin{array}{l}\text { Horseradish } \\
\text { peroxidase }\end{array}$ & $\begin{array}{l}\text { Covalent } \\
\text { immobilizati } \\
\text { on }\end{array}$ & $\begin{array}{l}\text { Acid Blue 113, } \\
\text { Acid Black 10 } \\
\text { BX }\end{array}$ & $\begin{array}{l}\mathrm{pH} 7,25 \\
{ }^{\circ} \mathrm{C}, 35 \\
\min \end{array}$ & $\begin{array}{l}95 \%, \\
90 \%\end{array}$ & [156] \\
\hline $\begin{array}{l}\text { Multi-walled carbon } \\
\text { nanotube/cordierite }\end{array}$ & $\begin{array}{l}\text { Horseradish } \\
\text { peroxidase }\end{array}$ & $\begin{array}{l}\text { Covalent } \\
\text { immobilizati } \\
\text { on }\end{array}$ & $\begin{array}{l}\text { 4- } \\
\text { aminoantipyrine }\end{array}$ & $\begin{array}{l}\mathrm{pH}^{\circ}, 25 \\
{ }^{\circ} \mathrm{C}, 1 \mathrm{~h}\end{array}$ & $96 \%$ & [157] \\
\hline $\begin{array}{l}\text { Silica/magnetic/ } \\
\text { methacrylyol particles }\end{array}$ & $\begin{array}{l}\text { Laccase from } \\
\text { Trametes } \\
\text { versicolor }\end{array}$ & $\begin{array}{l}\text { Adsorption } \\
\text { immobilizati } \\
\text { on }\end{array}$ & Methyl Red & $\begin{array}{l}\mathrm{pH} 6,35 \\
{ }^{\circ} \mathrm{C}, 12 \mathrm{~h}\end{array}$ & $90 \%$ & [158] \\
\hline $\begin{array}{l}\mathrm{Cu}^{2+} / \text { silica magnetic } \\
\text { particles }\end{array}$ & Laccase & $\begin{array}{l}\text { Covalent } \\
\text { immobilizati } \\
\text { on }\end{array}$ & $\begin{array}{l}2,4- \\
\text { dichlorophenol }\end{array}$ & $\begin{array}{l}\mathrm{pH} \mathrm{5,25} \\
{ }^{\circ} \mathrm{C}, 12 \mathrm{~h}\end{array}$ & $100 \%$ & [159] \\
\hline $\begin{array}{l}\text { Silica magnetic } \\
\text { particles }\end{array}$ & Laccase & $\begin{array}{l}\text { Covalent } \\
\text { immobilizati } \\
\text { on }\end{array}$ & $\begin{array}{l}2,4- \\
\text { dichlorophenol }\end{array}$ & $\begin{array}{l}\mathrm{pH} \mathrm{5,35} \\
{ }^{\circ} \mathrm{C}, 6 \mathrm{~h}\end{array}$ & $85 \%$ & [160] \\
\hline $\begin{array}{l}\text { Magnetic mesoporous } \\
\text { silica nanoparticles }\end{array}$ & $\begin{array}{l}\text { Laccase from } \\
\text { Trametes } \\
\text { versicolor }\end{array}$ & $\begin{array}{l}\text { Covalent } \\
\text { immobilizati } \\
\text { on }\end{array}$ & Phenol & $\begin{array}{l}25^{\circ} \mathrm{C} \\
40 \mathrm{~h}\end{array}$ & $90 \%$ & [161] \\
\hline $\begin{array}{l}\text { Magnetic tubular } \\
\text { mesoporous silica }\end{array}$ & Laccase & $\begin{array}{l}\text { Covalent } \\
\text { immobilizati } \\
\text { on }\end{array}$ & Methoxychlor & $\begin{array}{l}\mathrm{pH} 4.5 \\
35^{\circ} \mathrm{C} \\
10 \mathrm{~h}\end{array}$ & $69 \%$ & [162] \\
\hline $\begin{array}{l}\text { Magnetic } \\
\text { nanoparticles/ } \\
\text { graphene oxide } \\
\text { nanocomposite }\end{array}$ & $\begin{array}{l}\text { Horseradish } \\
\text { peroxidase }\end{array}$ & $\begin{array}{l}\text { Covalent } \\
\text { immobilizati } \\
\text { on }\end{array}$ & $\begin{array}{l}\text { 2-chlorophenol, } \\
\text { 4-chlorophenol, } \\
\text { 2,4- } \\
\text { dichlorophenol }\end{array}$ & $\begin{array}{l}\mathrm{pH} 6,25 \\
{ }^{\circ} \mathrm{C}, 3 \mathrm{~h}\end{array}$ & $\begin{array}{l}82 \%, \\
52 \%, \\
33 \%\end{array}$ & [163] \\
\hline $\begin{array}{l}\text { Carbon mesoporous } \\
\text { magnetic composites }\end{array}$ & $\begin{array}{l}\text { Laccase from } \\
\text { Trametes } \\
\text { versicolor } \\
\end{array}$ & $\begin{array}{l}\text { Covalent } \\
\text { immobilizati } \\
\text { on }\end{array}$ & $\begin{array}{l}\text { Phenol, } \\
p \text {-chlorophenol }\end{array}$ & $\begin{array}{l}\mathrm{pH} 6,45 \\
{ }^{\circ} \mathrm{C}, 12 \mathrm{~h}\end{array}$ & $\begin{array}{l}74 \%, \\
82 \%\end{array}$ & [164] \\
\hline $\begin{array}{l}\text { Magnetic chitosan/ } \\
\text { clay beads }\end{array}$ & $\begin{array}{l}\text { Laccase from } \\
\text { Trametes } \\
\text { versicolor }\end{array}$ & $\begin{array}{l}\text { Covalent } \\
\text { immobilizati } \\
\text { on }\end{array}$ & Phenol & $\begin{array}{l}\mathrm{pH} 5,25 \\
{ }^{\circ} \mathrm{C}, 4 \mathrm{~h}\end{array}$ & $80 \%$ & [165] \\
\hline $\begin{array}{l}\text { Superparamagnetic/ } \\
\text { chitosan microspheres }\end{array}$ & Tyrosinase & $\begin{array}{l}\text { Covalent } \\
\text { immobilizati } \\
\text { on }\end{array}$ & Phenol & $\begin{array}{l}\mathrm{pH} 7,25 \\
{ }^{\circ} \mathrm{C}, 48 \mathrm{~h}\end{array}$ & $65 \%$ & [166] \\
\hline $\begin{array}{l}\text { Cyanuric chloride/ } \\
\text { silica magnetic } \\
\text { nanoparticles }\end{array}$ & Tyrosinase & $\begin{array}{l}\text { Covalent } \\
\text { immobilizati } \\
\text { on }\end{array}$ & $\begin{array}{l}\text { 2,2'-azinobis- } \\
\text { (3- } \\
\text { ethylbenzothiazo } \\
\text { line-6-sulphonic } \\
\text { acid) }\end{array}$ & $\begin{array}{l}\mathrm{pH} \mathrm{7,35} \\
{ }^{\circ} \mathrm{C}, 1 \mathrm{~h}\end{array}$ & $95 \%$ & [167] \\
\hline Chitosan/ $\mathrm{SiO}_{2}$ gel & $\begin{array}{l}\text { Polyphenol } \\
\text { oxidase from } \\
\text { potato }\end{array}$ & $\begin{array}{l}\text { Covalent } \\
\text { immobilizati } \\
\text { on }\end{array}$ & Phenol & $\begin{array}{l}\mathrm{pH} 7,25 \\
{ }^{\circ} \mathrm{C}, 24 \mathrm{~h}\end{array}$ & $86 \%$ & [168] \\
\hline $\begin{array}{l}\text { Chitosan/biomimetic } \\
\text { silica nanoparticles }\end{array}$ & $\begin{array}{l}\text { Manganese } \\
\text { peroxidase from } \\
\text { Phanerochaete } \\
\text { chrysosporium }\end{array}$ & $\begin{array}{l}\text { Covalent } \\
\text { immobilizati } \\
\text { on }\end{array}$ & $\begin{array}{l}\text { 2,6- } \\
\text { dimethoxypheno } \\
1\end{array}$ & $\begin{array}{l}\mathrm{pH} 4.5, \\
30^{\circ} \mathrm{C}, 1 \\
\mathrm{~h}\end{array}$ & $95 \%$ & [169] \\
\hline $\begin{array}{l}\text { Chitosan/ } \mathrm{CeO}_{2} \text { micros } \\
\text { pheres }\end{array}$ & $\begin{array}{l}\text { Laccase from } \\
\text { Trametes } \\
\text { versicolor }\end{array}$ & $\begin{array}{l}\text { Covalent } \\
\text { immobilizati } \\
\text { on }\end{array}$ & $\begin{array}{l}\text { Methyl Red, } \\
\text { Orange II }\end{array}$ & $\begin{array}{l}\mathrm{pH} 6,25 \\
{ }^{\circ} \mathrm{C}, 9 \\
\text { days } \\
\end{array}$ & $\begin{array}{l}83 \%, \\
93 \%\end{array}$ & [170] \\
\hline Chitosan/clay & Tyrosinase from & Covalent & Phenol & $\mathrm{pH} \mathrm{7,25}$ & $100 \%$ & [171] \\
\hline
\end{tabular}




\begin{tabular}{|c|c|c|c|c|c|c|}
\hline composite & mushroom & $\begin{array}{l}\text { immobilizati } \\
\text { on }\end{array}$ & & ${ }^{\circ} \mathrm{C}, 6 \mathrm{~h}$ & & \\
\hline $\begin{array}{l}\text { Chitosan } \\
\text { nanoparticles/glass } \\
\text { beads }\end{array}$ & $\begin{array}{l}\text { Laccase } \\
\text { Paraconiothyrium } \\
\text { variabile }\end{array}$ & $\begin{array}{l}\text { Covalent } \\
\text { immobilizati } \\
\text { on }\end{array}$ & Congo Red & $\begin{array}{l}\text { pH 5, 40 } \\
{ }^{\circ} \mathrm{C}, 15 \\
\min \end{array}$ & $98 \%$ & {$[172]$} \\
\hline $\begin{array}{l}\text { Chitosan/ } \\
\text { polyacrylamide } \\
\text { hydrogel }\end{array}$ & $\begin{array}{l}\text { Laccase from } \\
\text { Trametes } \\
\text { versicolor }\end{array}$ & $\begin{array}{l}\text { Encapsulatio } \\
\mathrm{n}\end{array}$ & $\begin{array}{l}\text { Acid Orange 7, } \\
\text { Malachite Green }\end{array}$ & $\begin{array}{l}\mathrm{pH} \mathrm{5,25} \\
{ }^{\circ} \mathrm{C}, 6 \mathrm{~h}\end{array}$ & $\begin{array}{l}70 \%, \\
97 \%\end{array}$ & {$[173]$} \\
\hline $\begin{array}{l}\text { Chitosan/alginate/ } \\
\text { magnetic capsules }\end{array}$ & $\begin{array}{l}\text { Tyrosinase from } \\
\text { mushroom }\end{array}$ & $\begin{array}{l}\text { Encapsulatio } \\
\mathrm{n}\end{array}$ & $\begin{array}{l}\text { Phenol, } \\
\text { Bisphenol A }\end{array}$ & $\begin{array}{l}\mathrm{pH} 6,25 \\
{ }^{\circ} \mathrm{C}, 39 \mathrm{~h}\end{array}$ & $\begin{array}{l}100 \% \\
85 \%\end{array}$ & {$[174]$} \\
\hline $\begin{array}{l}\text { Magnetic } \mathrm{Cu} \text { alginate } \\
\text { beads }\end{array}$ & $\begin{array}{l}\text { Laccase from } \\
\text { Trametes } \\
\text { versicolor }\end{array}$ & $\begin{array}{l}\text { Encapsulatio } \\
\mathrm{n}\end{array}$ & $\begin{array}{l}\text { Triclosan, } \\
\text { Remazol } \\
\text { Brilliant Blue R }\end{array}$ & $\begin{array}{l}\text { pH 5.2, } \\
25^{\circ} \mathrm{C}, 8 \\
\text { h }\end{array}$ & $\begin{array}{l}89 \% \\
76 \%\end{array}$ & {$[175]$} \\
\hline Alginate/ $\mathrm{SiO}_{2}$ gel & $\begin{array}{l}\text { Polyphenol } \\
\text { oxidase from } \\
\text { potato }\end{array}$ & Entrapment & Phenol & $\begin{array}{l}\mathrm{pH} 7,25 \\
{ }^{\circ} \mathrm{C}, 8 \mathrm{~h}\end{array}$ & $90 \%$ & {$[176]$} \\
\hline $\begin{array}{l}\text { Poly(acrylamide- } \\
\text { crotonic acid)/ } \\
\text { Na alginate }\end{array}$ & $\begin{array}{l}\text { Laccase from } \\
\text { Trametes } \\
\text { versicolor }\end{array}$ & $\begin{array}{l}\text { Covalent } \\
\text { immobilizati } \\
\text { on }\end{array}$ & Acid Orang & $\begin{array}{l}\mathrm{pH} 4.5, \\
30^{\circ} \mathrm{C}, 6 \\
\mathrm{~h}\end{array}$ & $73 \%$ & {$[177]$} \\
\hline $\begin{array}{l}\text { Polyvinyl alcohol/ Ca } \\
\text { alginate beads }\end{array}$ & $\begin{array}{l}\text { Manganese } \\
\text { peroxidase from } \\
\text { Ganodermalucidu } \\
m \text { IBL-05 }\end{array}$ & Entrapment & $\begin{array}{l}\text { Sandal reactive } \\
\text { dyes, } \\
\text { Textile } \\
\text { wastewater }\end{array}$ & $\begin{array}{l}\mathrm{pH} 5,25 \\
{ }^{\circ} \mathrm{C}\end{array}$ & $\begin{array}{l}92 \%, \\
80 \%\end{array}$ & [178] \\
\hline $\begin{array}{l}\text { Polyamide } 6 / \text { chitosan } \\
\text { nanofibers }\end{array}$ & $\begin{array}{l}\text { Laccase from } \\
\text { Trametes } \\
\text { versicolor }\end{array}$ & $\begin{array}{l}\text { Covalent } \\
\text { immobilizati } \\
\text { on }\end{array}$ & $\begin{array}{l}\text { Bisphenol A, } \\
17-\alpha- \\
\text { ethinylestradiol }\end{array}$ & $\begin{array}{l}\mathrm{pH} 5,37 \\
{ }^{\circ} \mathrm{C}, 6 \mathrm{~h}\end{array}$ & $\begin{array}{l}92 \%, \\
100 \%\end{array}$ & {$[179]$} \\
\hline $\begin{array}{l}\text { Poly(2-chloroethyl } \\
\text { acrylate)/zeolite } \\
\text { particles }\end{array}$ & $\begin{array}{l}\text { Laccase from } \\
\text { Trametes } \\
\text { versicolor }\end{array}$ & $\begin{array}{l}\text { Covalent } \\
\text { immobilizati } \\
\text { on }\end{array}$ & $\begin{array}{l}\text { Reactive Red } \\
120\end{array}$ & $\begin{array}{l}\mathrm{pH} 6.5, \\
35^{\circ} \mathrm{C}, 3 \\
\mathrm{~h}\end{array}$ & $100 \%$ & {$[180]$} \\
\hline $\begin{array}{l}\text { poly(acrylic acid)/ } \\
\mathrm{SiO}_{2} \text { nanofibrous }\end{array}$ & Laccase & $\begin{array}{l}\text { Covalent } \\
\text { immobilizati } \\
\text { on }\end{array}$ & Triclosan & $\begin{array}{l}\mathrm{pH} 4,30 \\
{ }^{\circ} \mathrm{C}, 2 \mathrm{~h}\end{array}$ & $60 \%$ & {$[181]$} \\
\hline $\begin{array}{l}\text { Graphene oxide/latex } \\
\text { hydrogel }\end{array}$ & Laccase & $\begin{array}{l}\text { Covalent } \\
\text { immobilizati } \\
\text { on }\end{array}$ & $\begin{array}{l}\text { Remazol } \\
\text { Brilliant Blue R }\end{array}$ & $\begin{array}{l}\mathrm{pH} 4.5, \\
25^{\circ} \mathrm{C}, \\
17 \mathrm{~h}\end{array}$ & $100 \%$ & {$[182]$} \\
\hline $\begin{array}{l}\text { Cu tetra- } \\
\text { aminophthalocyanine } \\
\text { /magnetic } \\
\text { nanoparticles }\end{array}$ & $\begin{array}{l}\text { Laccase from } \\
\text { Pycnoporussangu } \\
\text { ineus }\end{array}$ & $\begin{array}{l}\text { Covalent } \\
\text { immobilizati } \\
\text { on }\end{array}$ & $\begin{array}{l}2,2 \text { '-azinobis- } \\
(3- \\
\text { ethylbenzothiazo } \\
\text { line-6-sulphonic } \\
\text { acid) }\end{array}$ & $\begin{array}{l}\mathrm{pH} 3,45 \\
{ }^{\circ} \mathrm{C}\end{array}$ & $100 \%$ & [183] \\
\hline $\begin{array}{l}\text { Poly(4-vinyl } \\
\text { pyridine)/Cu(II) } \\
\text { magnetic beads }\end{array}$ & $\begin{array}{l}\text { Laccase from } \\
\text { Trametes } \\
\text { versicolor }\end{array}$ & $\begin{array}{l}\text { Adsorption } \\
\text { immobilizati } \\
\text { on }\end{array}$ & $\begin{array}{l}\text { Reactive Green } \\
19, \\
\text { Reactive Red 2, } \\
\text { Reactive Brown } \\
10\end{array}$ & $\begin{array}{l}\text { pH 5.5, } \\
30^{\circ} \mathrm{C}, \\
18 \mathrm{~h}\end{array}$ & $\begin{array}{l}64 \%, \\
88 \%, \\
91 \%\end{array}$ & {$[184]$} \\
\hline $\begin{array}{l}\text { Poly } \\
(p- \\
\text { phenylenediamine)/ } \\
\text { magnetic } \\
\text { nanocomposite }\end{array}$ & Laccase & $\begin{array}{l}\text { Covalent } \\
\text { immobilizati } \\
\text { on }\end{array}$ & Reactive Blue 19 & $\begin{array}{l}\mathrm{pH} 4,25 \\
{ }^{\circ} \mathrm{C}, 2 \mathrm{~h}\end{array}$ & $90 \%$ & {$[185]$} \\
\hline $\begin{array}{l}\text { Poly(styrene-co- } \\
\text { methacrylic acid) } \\
\text { nanofibers }\end{array}$ & $\begin{array}{l}\text { Horseradish } \\
\text { peroxidase }\end{array}$ & $\begin{array}{l}\text { Covalent } \\
\text { immobilizati } \\
\text { on }\end{array}$ & $\begin{array}{l}- \\
\text { methoxyphenol }\end{array}$ & $\begin{array}{l}\mathrm{pH} \mathrm{5,2} \\
\mathrm{h}\end{array}$ & $80 \%$ & {$[186]$} \\
\hline $\begin{array}{l}\text { Poly(lactic-co- } \\
\text { glycolic acid) } \\
\text { nanofibers }\end{array}$ & $\begin{array}{l}\text { Laccase from } \\
\text { Pleurotusflorida }\end{array}$ & $\begin{array}{l}\text { Covalent } \\
\text { immobilizati } \\
\text { on }\end{array}$ & Diclofenac & $\begin{array}{l}\mathrm{pH} 4,30 \\
{ }^{\circ} \mathrm{C}, 5 \mathrm{~h}\end{array}$ & $100 \%$ & [187] \\
\hline Poly(acryl-amide) gel & $\begin{array}{l}\text { Manganese } \\
\text { peroxidase from } \\
\text { Ganodermalucidu } \\
m \text { IBL-05 } \\
\end{array}$ & Entrapment & Textile dyes & $\begin{array}{l}\text { pH 5.5, } \\
30^{\circ} \mathrm{C}\end{array}$ & $>70 \%$ & {$[188]$} \\
\hline
\end{tabular}




\begin{tabular}{|c|c|c|c|c|c|c|}
\hline $\begin{array}{l}\text { Poly(methyl } \\
\text { methacrylate-co- } \\
\text { glycidyl methacrylate) } \\
\text { cryogel }\end{array}$ & $\begin{array}{l}\text { Laccase from } \\
\text { Trametes } \\
\text { versicolor }\end{array}$ & $\begin{array}{l}\text { Covalent } \\
\text { immobilizati } \\
\text { on }\end{array}$ & $\begin{array}{l}\text { Procion Red, } \\
\text { Reactive Green } \\
5, \\
\text { Reactive Brown } \\
\text { 10, } \\
\text { Reactive Green } \\
\text { 19, } \\
\text { Cibacron Blue } \\
\text { F3GA, } \\
\text { Alkali Blue 6B, } \\
\text { Brilliant Blue } 6\end{array}$ & $\begin{array}{l}\mathrm{pH} 4,45 \\
{ }^{\circ} \mathrm{C}, 10 \mathrm{~h}\end{array}$ & $\begin{array}{l}81 \%, \\
60 \%, \\
74 \%, \\
66 \%, \\
63 \%, \\
60 \%, \\
62 \%\end{array}$ & [189] \\
\hline $\begin{array}{l}\text { Poly(vinyl alcohol)/ } \\
\text { 4-hydroxybenz- } \\
\text { aldehyde cinnamate }\end{array}$ & $\begin{array}{l}\text { Horseradish } \\
\text { peroxidase }\end{array}$ & $\begin{array}{l}\text { Covalent } \\
\text { immobilizati } \\
\text { on }\end{array}$ & $\begin{array}{l}\text { 2,2'-azinobis- } \\
\text { (3- } \\
\text { ethylbenzothiazo } \\
\text { line-6-sulphonic } \\
\text { acid) }\end{array}$ & $\begin{array}{l}\mathrm{pH} 4.5, \\
25^{\circ} \mathrm{C}\end{array}$ & $98 \%$ & [190] \\
\hline
\end{tabular}


Figure 1

(a)<smiles>CC(C)(c1ccc(O)cc1)c1ccc(O)cc1</smiles><smiles>IC1(I)CCCCC1</smiles><smiles>CC(C)(c1ccc(O)cc1)c1ccc(O)cc1</smiles>

BPA dimer<smiles>Cc1cc(C(C)(C)c2ccc(O)cc2)ccc1O</smiles>

BPA oligomer

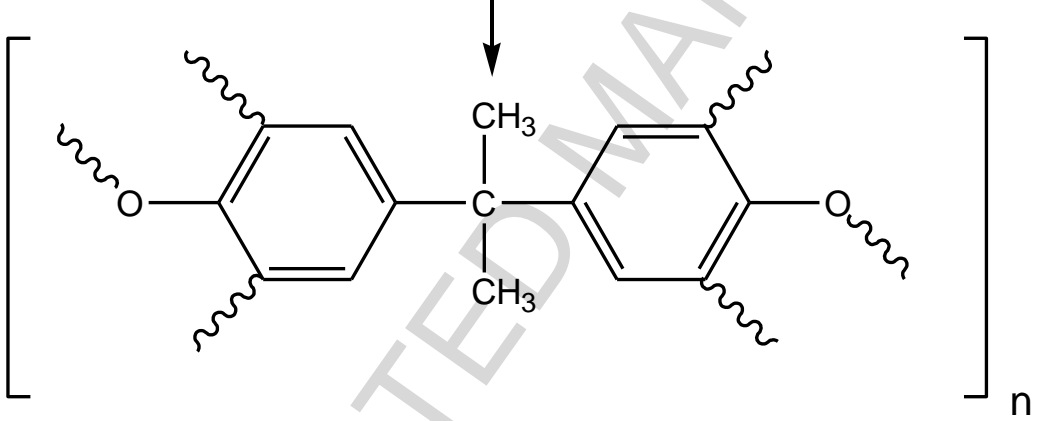

นns = C-O or C-C bonds 


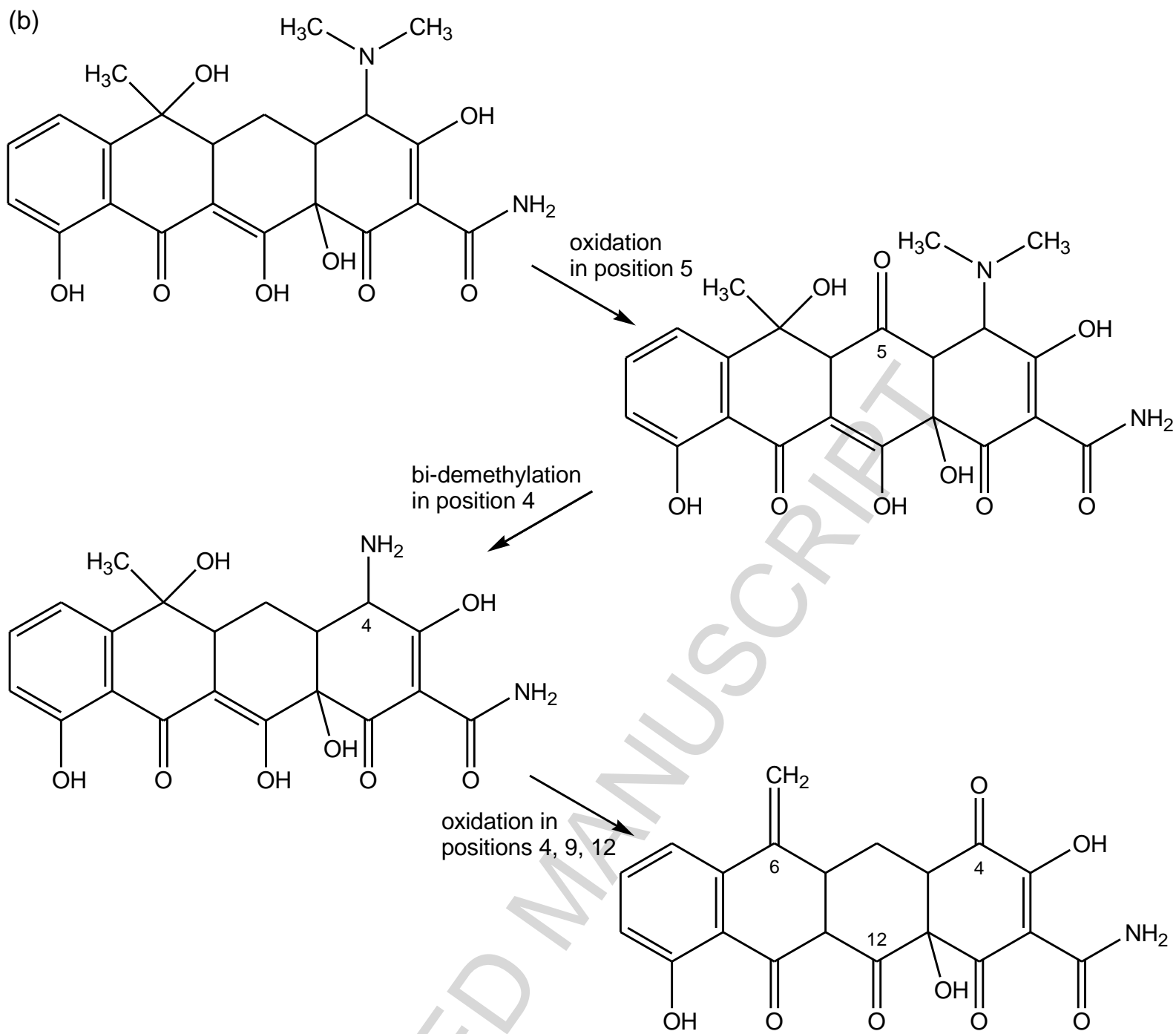


Figure 2

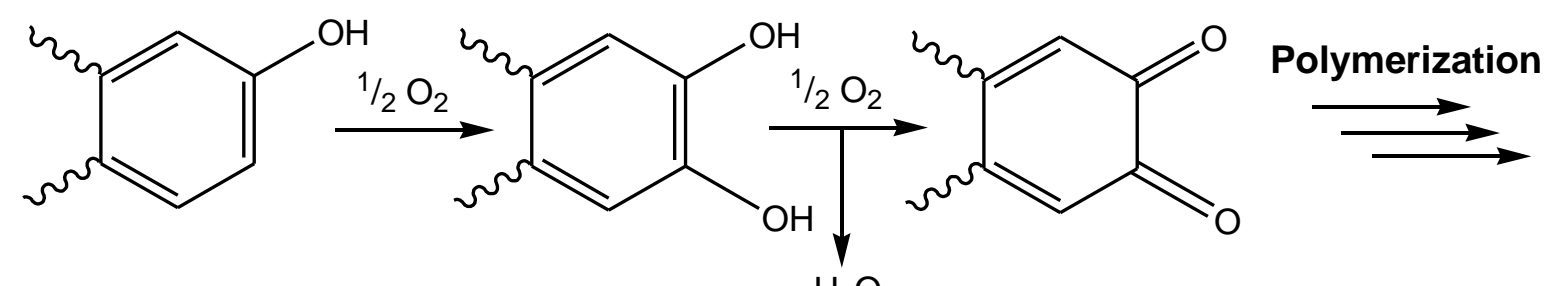

Phenolic compound 


\section{Figure 3}

Organic materials presence of numerous of reactive functional groups,

high affinity for peptides, biocompatibility, limited negative effect on enzyme structure, abundant in nature

biopolymers: chitosan, alginates, cellulose, carrageenan, collagen, agar synthetic polymers: ion exchange resins, polystyrene, polyamide, polyacrylonitrile

Inorganic materials temperature and $\mathrm{pH}$ stability, mechanical resistance, operational stability, good sorption properties, inertness, easy surface functionalization, relatively cheap

silica, titania, alumina, zirconia, zinc oxide, magnetite, kaolin, hydroxyapatite, halloysite, active carbons multi-walled carbon nanotubes, porous glass, noble metals

Hybrid and composite materials reusability of the matrix, strong binding of the enzyme, high stability, properties of the support material designed for selected enzyme and catalytic process

silica-magnetite, silica-zinc oxide, chitosan-silica, chitosan-clay, alginate-chitosan, polyamide-chitosan, polilactic-polyglycolic acid, polyvinyl alcohol-4-hydroxybenzaldehyde 


\section{Figure 4}

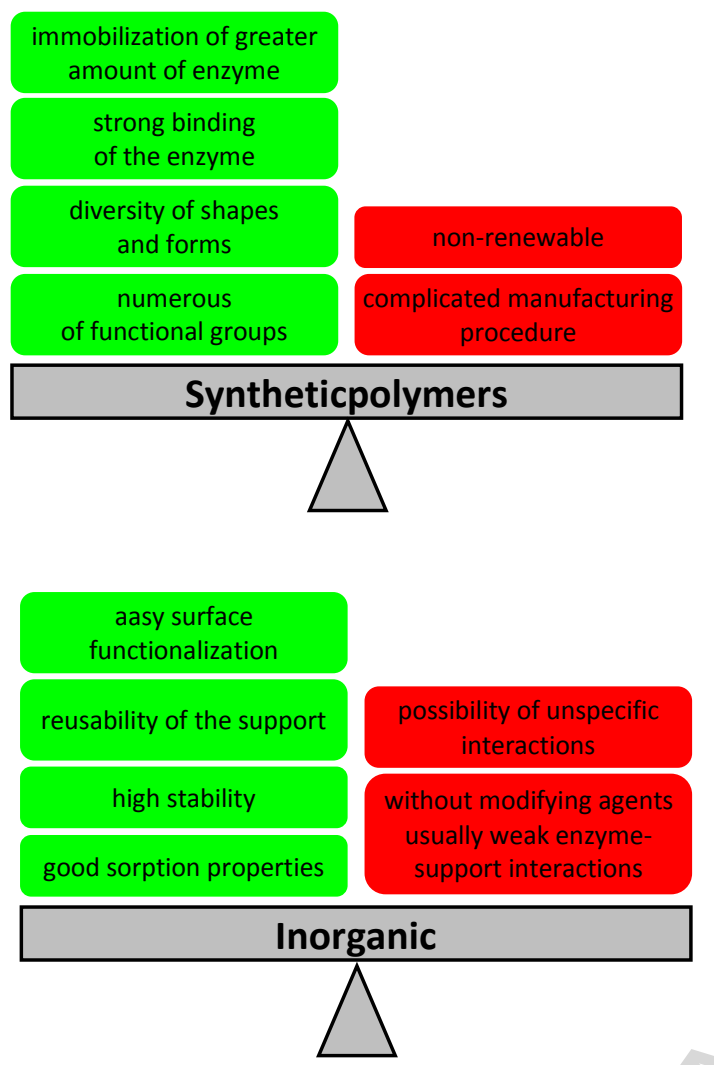

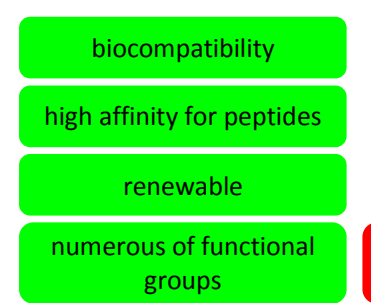

necessity of clearing and proper preparation

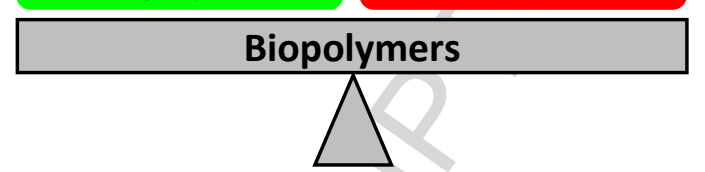

applied in all immobilization techniques

strong, multipoint binding of the enzyme

limited enzyme leakage

tailor-made supports

Hybrids/composites 
Figure captions:

Figure 1.

Degradation pathways of: (a) bishenol A and (b) tetracycline by laccase (adapted from [32] and [33]).

\section{Figure 2.}

Catalytic pathway of phenolic substrate by tyrosinase.

\section{Figure 3.}

Selected examples and the most important properties of support materials used for immobilization of enzymes for environmental application.

\section{Figure 4.}

Summary of advantages and disadvantages of support materials for immobilization of oxidoreductases. 
Highlights

- Recent advances of carriers for immobilization of oxidoreductases are presented.

- Features of the various support materials are summarized and discussed.

- Selection of support material depends of enzyme and immobilization protocol.

- Properties and advantages of different oxidoreductases are highlighted.

- Application of immobilized enzymes for removal of hazardous pollutants is reviewed. 